\title{
Third Program Plan for DOE'S Participation in the IEA Working Party on Energy Conservation Research and Development
}

June 1980

Prepared for:

U.S. Department of Energy

Assistant Secretary for Conservation and Solar Energy

Under Contract No. DE-AC01-79CS20095 


\section{DISCLAIMER}

This report was prepared as an account of work sponsored by an agency of the United States Government. Neither the United States Government nor any agency Thereof, nor any of their employees, makes any warranty, express or implied, or assumes any legal liability or responsibility for the accuracy, completeness, or usefulness of any information, apparatus, product, or process disclosed, or represents that its use would not infringe privately owned rights. Reference herein to any specific commercial product, process, or service by trade name, trademark, manufacturer, or otherwise does not necessarily constitute or imply its endorsement, recommendation, or favoring by the United States Government or any agency thereof. The views and opinions of authors expressed herein do not necessarily state or reflect those of the United States Government or any agency thereof. 


\section{DISCLAIMER}

Portions of this document may be illegible in electronic image products. Images are produced from the best available original document. 


\section{NOTICE}

This report was prepared as an account of work sponsored by the United States Government. Neither the United States nor the United States Department of Energy, nor any of their employees, makes any warranty, express or implied, or assumes any legal liability or responsibility for the accuracy, completeness, or usefuiness of any information, apparatus, product, or process disclosed, or represents that its use would not infringe privately owned rights. Reference herein to any specific commercial product, process, or service by trade name, mark, manufacturer, or otherwise, does not necessarily constitute or imply its endorsement, recommendation, or favoring by the United States Government or any agency thereof. The views and opinions of authors expressed herein do not necessarily state or reflect those of the United States Government or any agency thereof.

Available From:

National Technical Information Service (NTIS)

U.S. Department of Commerce

5285 Port Royal Road

Springfield, Virginia 22161

Price: Printed Copy: $\$ 6.00$

Microfiche: $\$ 4.00$ 


\section{Third Program Plan for DOE'S Participation in the IEA Working Party on Energy-Conservation Research and Development}

June 1980

Prepared by:

Resource Planning Associates

WashingtonD.C. 20036

Under Contract No. DE-AC01-79CS20095

Prepared for:

U.S. Department of Energy

Assistant Secretary for Conservation and Solar Energy

Washington D.C. 20585

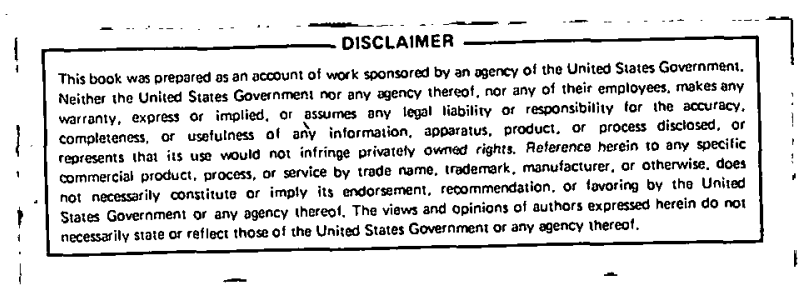


I am pleased 'to present the 1980 Program Plan for DOE's participation in the International Energy Agency's (IEA) Working Party on Energy Conservation Research and Development. The plan documents the projects currently being conducted by the working party in which DOE is participating and the projects proposed by DOE for consideration by other IEA member nations.

The Program Plan is intended to inform interested parties about DOE's IEA activities. It is also hoped that the plan will serve as a model for other working party participants in their efforts to document their current activities and plan their future commitments to IEA projects.

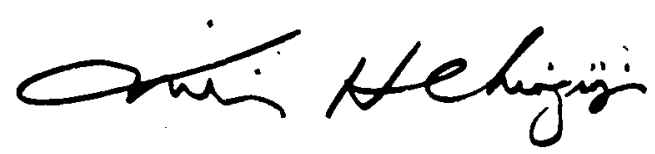

Dr. Melvin H. Chiogioji

Past Chairman

Working Party on Energy Conservation

Research and Development 


\section{Contents}

CHAPTER

INTRODUCTION

CHAPTER 1

CHAPTER 2

APPENDIX A

APPENDIX B

APPENDIX C
PAGE

TITLE
1 Current and Planned DOE Commitments Under Existing Implementing Agreements

5 Buildings and Community Systems

13 Energy Conservation in Building Complexes

15 Energy Cascading

19. Heat Pumps with Thermal Storage

21 Advanced Heat Pumps

25 Combustion

29 Heat Transfer and Heat Exchangers

33 Energy Storage

38 Cement Manufacture

40 High-Temperature Materials for Automotive Propulsion Systems

44 Planned DOE Commitments Under New Implementing Agreements

48 Combustion

50 Pulp and Paper

56 Iron and Steel

58 Food Processing .

62 Urban Waste

64 Alcohol Additives to Fuel

66 Mechanisms for Establishing Implementing Agreements and Annexes

68 Working Party Members

74 Evaluation Methodology 


\section{Introduction}

In response to the oil crisis of 1973, the United States urged the international community to develop a program of cooperative action for dealing with the changing world energy situation. As a result of the United States' initiative, the International Energy Agency (IEA) was established in November 1974, within the framework of the Organization for Economic Conperation and Development (OECD). The original members were: Austria, Belgium, Canada, Denmark, Federal Republic of Germany, Ireland, Italy, Japan, Luxembourg, the Netherlands, Spain, Sweden, Switzerland, Turkey, the United Kingdom, and the United States. Australia, Greece, and Portugal have subsequently joined the IEA; the European Community also participates in the work of the agency.

IEA was organized into a Governing Board composed of one or more ministers or their delegates from each participating country; a Management Committee composed of one or more senior representatives of the government of each participating country; and a Secretariat, which is the IEA's administrative body. Four standing groups and a committee were then formed in 1974 and 1975, each with a specific objective (see Exhibit 1). The Standing Group on Emergency Questions was formed to take common, effective measures to meet oil-supply emergencies by encouraging selfsufficiency in oil supplies, restraining demand, and allocating supplies among member countries on an equitable basis. The Standing Group on the Oil Market was charged with promoting secure oil supplies on reasonable and equitable terms for member nations. The Standing Group on Relations with Producer and Other Countries was formed to promote cooperative relations with oilproducing countries. Finally, the Committee on Energy Research and Development (R\&D) and the Standing Group on Long-Term Cooperation shared responsibility for reducing the dependence of member countries on imported oil by undertaking long-term cooperative efforts on conservation of energy, accelerated development of alternative sources of energy, and energy-related R\&D.

The United States has been most actively involved in IEA activities conducted under the Committee on Energy R\&D.

Under the committee, member nations interested in developing and conducting cooperative R\&D. projects establish working parties. Currently, 12 working parties have been established:

- Biomass Conversion

- Fusion

- Geothermal Energy

- Coal Technology

- Energy R\&D Strategy

- Energy Conservation R\&D

- Hydrogen Production from Water

- Ocean Energy Systems

- Radioactive Waste Management

- Small Solar Power Systems

- Solar Heating and Cooling

- Wind Power.

Various United States agencies are participating in all 12 working parties. 
The Working Party on Energy Conservation R\&D was established in March 1977 by the Committee on Energy R\&D to promote international cooperative R\&D programs focusing on new energy conservation technologies. The working party has four objectives:

- To develop international mechanisms for performing energy conservation research, development, and demonstration (RD\&D) with maximum benefits to participants, and to accelerate the realization of those benefits.

- To identify areas of mutual interest that represent major opportunities for more efficient use or for conservation of energy

- To define and implement mechanisms to develop and exchange information and/or R\&D results

- To perform RD\&D projects that maximize cooperation between national R\&D programs.

The U.S. Department of Energy (DOE) is responsible for coordiriating U.S. involvement in the working party and for ensuring that U.S. interests are directly served by this involvement. DOE also ensures that the United States achieves several specific objectives by cosponsoring IEA projects:

- Optimize domestic RD\&D expenditures

- Promote the development of U.S. industries

- Contribute to the preservation of economic and political stability in the free world .

- Strengthen the international position of the United States.

To ensure that these objectives are achieved, each division uses its own existing evaluation techniques. Furthermore, the chairman of the working party has developed an appraisal method for evaluating IE $\wedge$ projects in which it is involved or in which it may be interested in participating. Each project must be rigorously evaluated and justified before it is funded by Congress, during the annual review of the DOE budget (see Appendix A). After a project is funded, DOE contacts other IEA member nations to decide on appropriate project areas for cooperative RD\&D. They form an ad hoc committee, called an expert group, to draft an implementing agreement, which serves as the legal basis for cooperative RD\&D in that project area. After the agreement is signed, annexes are drafted under the agreement to outline the objectives and technical basis for specific projects undertaken within the project area (see Appendix B). The Working Party on Energy Conservation R\&D now has 10 signed implementing agreements; 6 new implementing agreements are being considered.

This program plan for DOE participation in the Working Party on Energy Conservation R\&D covers DOE's FY 1980 commitments to the signed and new implementing agreements. The plan describes each implementing agreement and related annexes, including the tasks, project status, other participants in the agreement, and financial arrangements. Chapter 1 reviews current and planned DOE commitments to existing implementing agreements; Chapter 2 reviews plarined DOE commitments to new implementing agreements. Appendix A discusses the mechanisms for establishing implementing agreements and annexes; $A p p e n d i x B$ is a list of members of the Working Party on Energy Conservation R\&D; and Appendix $C$ describes the evaluation methodology. 
Exhibit 1

International Energy Agency Organizational Structure

Working parties established under the Committee on Energy R\&D.

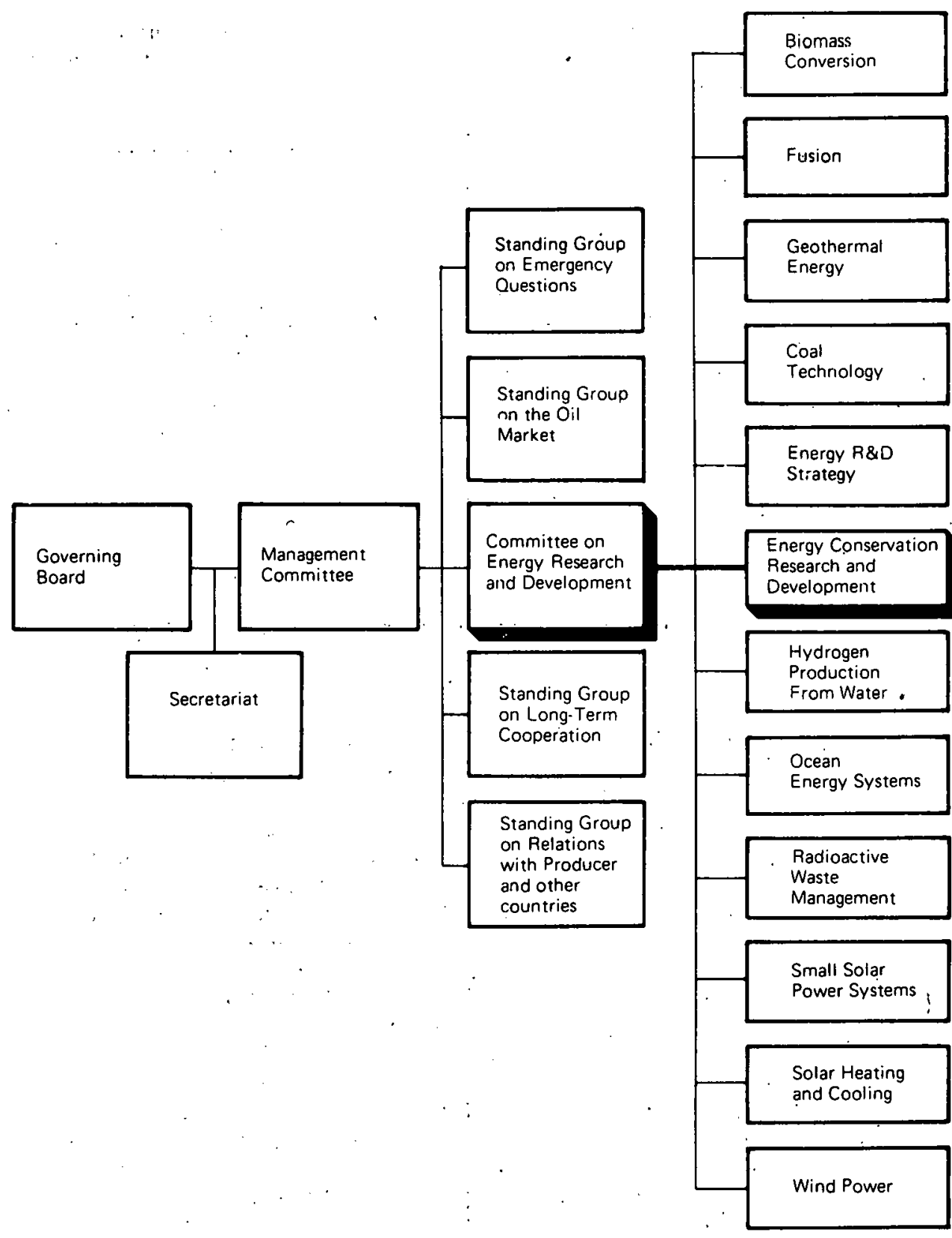




\section{Current and Planned DOE Commitments Under Existing Implementing Agreements}


The Working Party on Energy Conservation R\&D is presently sponsoring work under implementing agreements in ten areas:

- Buildings and Community Systems

- Energy Conservation in Building Complexes

- Energy Cascading

- Heat Pumps with Thermal Storage

- Advanced Heat Pumps

- Combustion

- Heat Transfer and Heat Exchangers

- Energy Storage

- Cement Manufacture

- High-Temperature Materials for Automotive Propulsion Systems.

DOE has made commitments to all these agreements and is currently participating in 14 of the 20 annexes under way i. these areas (see Exhibit 2). DOE has taken the lead in 7 annexes. Of the annexes, 8 are jointly funded (i.e., all contributions are pooled) and 12 are funded on a task-sharing basis (i.e., each country bears its own costs).

The agreements in which DOE is involved are an integral part of each division's program and contribute to the objectives of DOE's National Energy Plan. All agreements are monitored using the management review and control documents.

The United States, together with the other members of the Conservation Working Party, is currently discussing the establishment of six new implementing agreements in the areas of:

- Combustion

- Pulp and Paper

- Iron and Steel

- Food Processing

- Urban Waste

- Alcohol Additives to Fuels. 
Exhibit 2

Participants in Existing Implementing Agreements

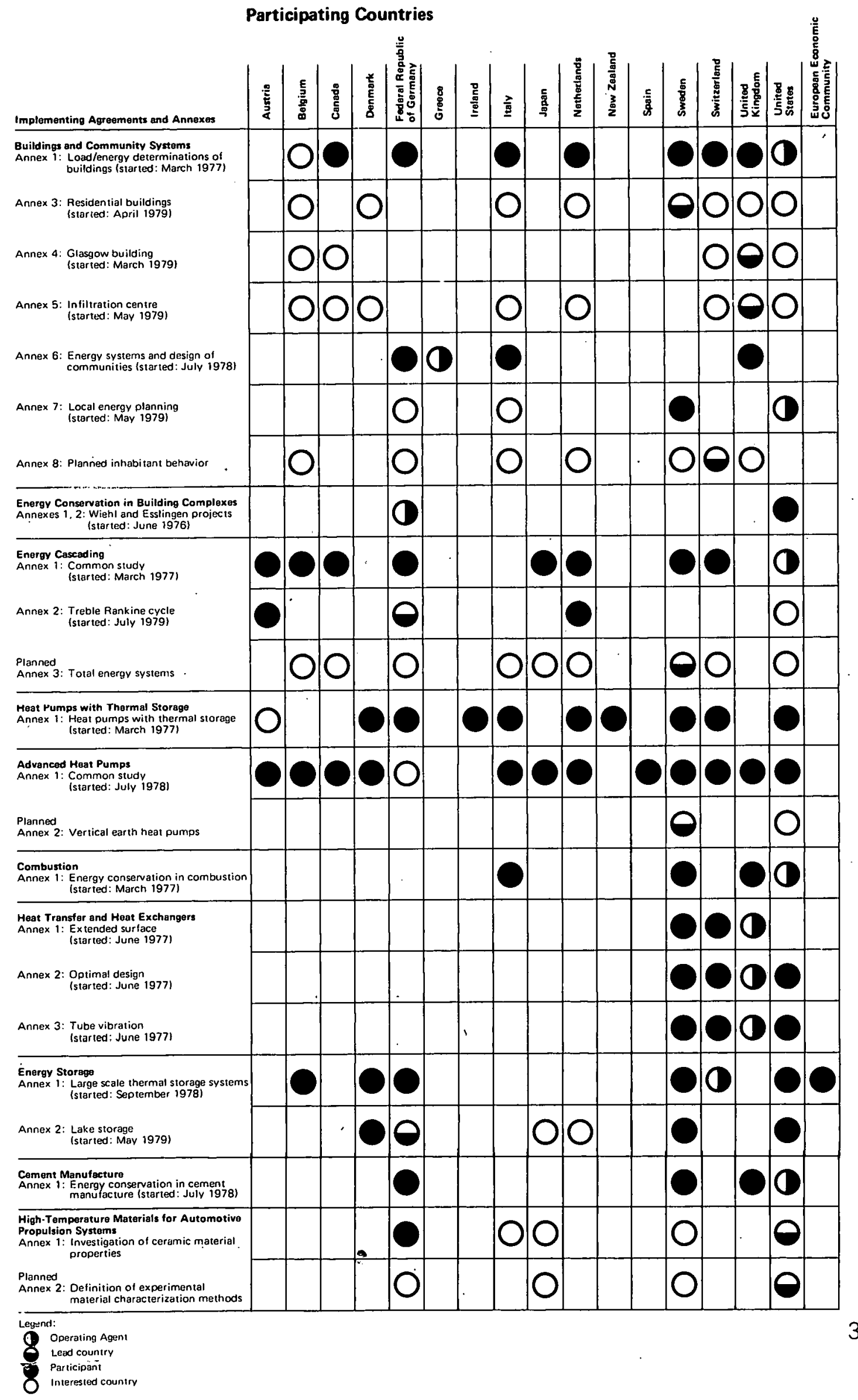




\section{THIS PAGE \\ WAS INTENTIONALLY \\ LEFT BLANK}




\section{Buildings and Community Systems}

In addition, the following annexes have been proposed:

Minimum Ventilation Standards under the lead of the Federal Republic of Germany; International Exchange of Computer Software and Central Library, United Kingdom; and Study of Efficiency of Appliances and Ways to Reduce Electricity Consumption in Residential and Commercial Sectors, Belgium.

Legal Status: $\quad$ The implementing agreement was signed in March 1977.

\section{Executive Committee David Curtis, Oscar Faber, Partners, United Kingdom \\ Chairman:}

Participants:

Canada, Denmark, FRG, Greece, Italy, Netherlands, Sweden, Switzerland, United Kingdom, United States. Belgium intends to sign.

\section{U.S. Program}

Howard Ross, DOE/BCS, (202) 252-9187

\section{Manager:}

\section{Schedule of Executive} Committee Meetings:

June 26-27, 1980; Washington, D.C., U.S.A.

December 10-11, 1980; Athens, Greece

Project Area Objectives: The buildings and community systems project represents a long-term effort undertaken, at U.S. initiative, to provide the parlicipating nations with international standards to evaluate, predict and compare energy usage for various energy systems, materials, buildings, and community designs.

The objective of this project is to examine different alternatives for energy conservation through improved design of buildings and community systems. Within this framework, the participating countries will be able to develop internationally accepted measurement techniques and to establish common codes and standards to improve energy conservation in new and existing buildings and communities.

Research is being conducted or is planned in eight areas:

Annex 1:

Annex 2:

Annex 3:

Annex 4:

Annex 5:

Annex 6:

Annex 7:

Planned Annexes

Annex 8:
Methodologies for Load/Energy Determination of Buildings

Energy Systems and Design of Communities (now Phase I of Annex 6)

Evaluation of Energy Conservation in Residential Buildings

Glasgow Commercial Building Monitoring Project

Air Infiltration Centre

Energy Systems and Design of Communities, Phases I and II

Local Energy Planning

Inhabitant Behavior with Regard to Ventilation. 


\section{BUILDINGS AND

\section{ANNEX 1: \\ METHODOLOGIES FOR LOAD/ENERGY DETERMINATION OF BUILDINGS}

Project Description: The objective of this project is twofold:

- To compare results of computer programs modeling energy loads and consumption in a commercial building

- To compare results of the same computer programs with measured values in an actual building.

In the first area, 19 programs from 8 countries have been compared on a hypothetical building specification to isolate key differences between programs in estimating building energy loads. Major differences were found between the programs in the handling of solar insolation effects. In the second area, the load estimates of the same programs are being compared with the actual loads and energy requirements of a real building, the Avonbarlk building in the United Kingdom. Initial results were difficult to compare because of varying interpretations of the specifications; a second comparison was made (on a voluntary basis).

A final report will be published in mid 1980.

Legal Status:

Operating Agent:

Participants:

U.S. Program Manager:

Project Financing:
The annex took effect on March 16, 1977

- United States, Department of Energy; Oscar Faber Partners, United Kingdom, as of June 1979

Canada, Denmark, FRG, Italy, Netherlands, Sweden, Switzerland, United Kingdom, United Slates. Belgium intends to sign.

Howard Ross, DOE/BCS, (202) 252-9187

The project is funded on a task-sharing basis. 


\section{BUILDINGS AND. COMMUNITY SYSTEMS}

\section{ANNEX 3: \\ EVALUATION OF ENERGY CONSERVATION IN RESIDENTIAL BUILDINGS}

Project Description: The objcctive of the project is to apply the Annex 1 methodology to residential buildings.

The main problem is using the methodology on an international basis, so that findings in one country can also be used in another, and extensive national research programs can then be reduced and rationalized.

Subtask $A$ of the annex is a comparison of manual and computer calculation methods to predict energy consumption in residential buildings. The influence of habitants will be taken into account. Subtask $B$ is to publish a handbook of guiding principles concerning design of experiments, instrumentation, and measuring techniques. A window design and standards conference will be held in June 1980 in connection with Subtask B. Subtask C is to evaluate national case studies and to . generalize them for other countries. The United States is participating in Subtasks B and C.

Periodic documents and reports on the results of the three subtasks will be published by the Operating Agent.

Legal Status:

Operating Agent:

Interested Countries:

\section{U.S. Program \\ Manager:}

Project Financing:

Schedule of Working Meetings:
This annex took effect on April 26, 1979; (duration: 3-1/2 years)

Sweden (National Council for Building Research)

Belgium, Denmark; Italy, Netherlands, Sweden, Switzerland, United States. Australia has indicated an interest in participating.

Howard Ross, DOE/BCS, (202) 252-9187

The project is funded on a task-sharing basis.

March 4-6, 1980; Zurich, Switzerland

June 9-13, 1980; Delft, the Netherlands 


\section{BUILDINGS AND COMMUNITY SYSTEMS}

\section{ANNEX 4: GLASGOW COMMERCIAL BUILDING MONITORING PROJECT}

Project Description: The primary objective of this project is to measure in detail the energy inputs, flows, and outputs, and the internal and external environment of a commercial office building. These data will allow in-depth comparisons of the actual energy performance of the building with that predicted by load/energy computer programs. This will lead in turn to a better understanding of energy transfers in buildings and to improve computer programs. A secondary objective of this task is to extend and further the evaluation of computerized energy analysis techniques begun under Annex 1.

The monitored building is the Collins Publishers building in Glasgow, Scotland.

Legal Status:

Operating Agent:

Interested Countries:

U.S. Program Manager

Project Financing:
This annex took effect on March 31, 1979; (duration: 3 years)

United Kingdom, University of Glasgow

Belgium, Canada, Switzerland, United Kingdom, United States. Australia, the FRG, and Japan are interested in participating.

Howard Ross, DOE/BCS, (202) 252-9187

The project is jointly funded as follows (British pounds sterling):

Belgium

24,000

48,000

24,000

Switzerland

96,000

University of Glasgow

38,000

Schedule of Working

October 1, 1980; Glasgow, U.K.

Meetings:

*The United States is also making an in-kind contribution of automated air infiltration measuring equipment. 


\section{ANNEX 5: \\ AIR INFILTRATION CENTRE}

Project Description: An Air Infiltration Centre $(A \mid C)$ has been established to coordinate research work in air infiltration and to support organizations active in air infiltration research through collation, analysis appraisal, and dissemination of experimental data and technical information. The AIC is located at the Building Services Research and Information Association in the United Kingdom. The program includes publication of a handbook on reduction of air infiltration in buildings.

\section{Legal Status:}

Operating Agent:

Interested Countries:

\section{U.S. Program \\ Manager:}

Project Financing:

Schedule of Working Meetings:
This annex took effect in May 1979

United Kingdom, Building Services Research and Information Association

Canada, Denmark, Italy, Netherlands, Sweden, Switzerland, United Kingdom, United States

Howard Ross, DOE/BCS, (202) 252-9187

The project is annually jointly funded as follows (British pounds sterling):

- Canada

Denmark

Italy

Netherlands

Switzerland

United Kingdom

United States

Sweden

18,400

4,600

18,400

9.200

9,200

36,800

36,800

Expenses incurred

in preparation of handbook

March 26, 1980; Copenhagen, Denmark (Centre Steering Group meeting),

October 6-8, 1980; AIC, Bracknell, U.K.

October 9, 1980; London, U.K. 


\section{BUILDINGS AND \\ COMMUNITY SYSTEMS}

\section{ANNEX 6: \\ ENERGY SYSTEMS AND DESIGN OF \\ COMMUNITIES (PHASES I AND II)}

Project Description: The objective of this two-phase effort is to increase understanding of townplanning procedures and the general analytical tools that can be used in design and development of more energy-efficient/energy-conscious communities.

In the first phase, various design-methodologies (as applied to the analysis of energy systems) were examined in a common study.

In the second phase, the participants are preparing case studies as a source of town-planning practices and general analytical tools with which to develop town-planning approaches that city planners can use. Workshops will be held to discuss the case studies.

Legal Status:

Operating Agent:

Participants:

\section{U.S. Program}

Manager:

Project Financing:

(

Schedule of Working

Meetings:
The annex took effect in July 1978; revised annex. took effect in January 1980 (duration: to December 30, 1980)

Greece, National Energy Council of the Ministry of Coordination of the Republic of Greece

FRG, Greece, Italy, United States

Gerald Leighton, DOE/BCS, (202) 252-9386

The work completed during Phase I was jointly funded, but Phase II will be funded on a task-sharing basis.

June 24-25, 1980; Washington, D.C., U.S.A. 


\section{ANNEX 7: \\ LOCAL ENERGY PLANNING}

Project Description: This project is comprised of six tasks addressing a range of issues dealing with local energy conservation opportunities and problems.

In the consumer preferences and needs area, the objective of the task is to survey and analyze information on consumer preferences and needs, and their effect on energy consumption, and to prepare a report on information and education programs that can reduce energy consumption.

In the building codes, loans, and grants area, the objectives are to compare the technical aspects and implementation procedures of building codes and regulations concerning loan and grant programs; to determine the effect of building codes and loan and grant programs on energy consumption; and to perform a cost-benefit analysis of possible improvements in building codes and loan and grant programs.

In the local government area, the objectives are to survey and assess the role of local governments in dealing with energy supply and demand problems; identify technical and institutional issues associated with alternative energy supply systems; and examine the energy conservation potential of underground structures.

Legal Status:

Operating Agent:

Participants:

\section{U.S. Program Manager:}

Estimated Maximum U.S. Invovlement:

Schedule of Working Meetings:
The annex was formally adopted, with minor revisions, on May 25, 1979 at an Executive Committee meeting

United States

Sweden, United States; Italy and Germany are interested in participating

Gerald S. Leighton, DOE/BCS, (202) 252-9386

The project will be funded on a task-sharing basis

February 1980; Washington, D.C., U.S.A.

April 15-19, 1980; Stockholm, Sweden

June 24-25, 1980, Washington, D.C. 
PLANNED ANNEX 8:

INHABITANT BEHAVIOR WITH

REGARD TO VENTILATION

Project Description: The objective of this project is to establish objective criteria for ventilation standards, and establish minimum ventilation standards based on activity, air quality, comfort, and moisture.

Legal Status:

The annex is in draft form and is expected to take effect in the summer of 1980

Lead Country:

Switzerland

Interested Countries:

Belgium, FRG, Italy, Netherlands, Sweden, United Kingdom

Schedule of

May 8-9, 1980; Zurich, Switzerland

Working Meetings: 


\section{Energy Conservation in Building Complexes}

Project Area Objectives: This project is a bilateral agreement between the Federal Republic of Germany (FRG) and the United States to design, implement, and perform experiments and to share information and evaluations on two building complexes at Esslingen and Wiehl, FRG. Demonstrations of heat pumps and other advanced energy systems will be conducted at the facilities.

Both the Wiehl and Esslingen sites are now in operation, and the FRG and the United States are negotiating the exchange of technical personnel and the project report requirements.

Work is under way in Annex 1: Wiehl demonstration project and Annex 2: Esslingen demonstration project.

Legal Status: $\quad T h e$ implementing agreement was signed on June 28, 1976 (duration: 5 years)

\section{Executive Committee} Chairman:

\section{Participants:}

\section{U.S. Program}

Manager:
Gerald S. Leighton, U.S. Department of Energy; Dr. Helmut Klein, Bundes Ministerium fur Forschung und Technologie, FRG

FRG, United States

Gerald S. Leighton, DOE/BCS, (202) 252-9386 


\section{Energy Conservation in Building Complexes}

\section{ANNEXES 1 AND 2: WIEHL AND ESSLINGEN TEST FACILITIES}

Project Description: The Wiehl large-scale experimental plant project involves a multi-purpose community recreational facility with integrated energy subsystems (e.g., waste-heat utilization, heat recovery from wastewater and ventilation exhaust, wastewater utilization, heat-loss reduction, solar-energy collection, heat pumps). Operating tests, analyses, and technological studies and evaluations will be conducted over a period of 5 to 10 years. Automatic data-collection systems have been installed and iritial test runs are under way.

The following deliverables should be supplied to the contracting parties by the Operating Agent:

- Preliminary report of winter operating season - due in January of each year

- Full report of winter operating season-due in May of each year

- Preliminary report of summer operating season - due in July of each year

- Full report of summer operating season-due in October of each year.

In the Esslingen project, virtually all space heating and domestic hot water requirements for a complex of three high-rise apartment buildings are provided by a central water-to-water heatpump system that extracts heat from river water. In addition, the heat pumps are used to form ice for a skating rink. The other primary systems are solar collectors, various semipassive and passive solar pool heating systems, and ground storage of thermal energy. The building complex has a backup oil-fired heating system that can meet the full heating requirements of the complex. The performance of the heat-pump system will be compared with that of the oil-fired heating system. Automatic data-collection systems have been installed and initial test runs are under way.

Legal Status:

Operating Agent:

Participants:

\section{U.S. Program Manager:}

Project Financing:
Annexes took effect on June 28, 1976

FRG

FRG, United States

Gerald S. Leighton, DOE/BCS, (202) 252-9386

This project was jointly funded as follows (U.S. dollars):

FRG 365,260 - (Initial Ivestment: 5,000,000)

U.S. $\quad 156,540-$ (Inital Investment: 150,000) 


\section{Energy Cascading}

Project Area Objectives: The objective of this project is to study ways of exploiting useful R\&D work in primary fuels. Technologies being studied include those using the thermofluents cascading frum high temperatures through thermocycles, discharging heat to the environment or to low-temperature fluents. Other technologies being studied are those used to capture wasteheat streams. In general, cascading systems are of the following types: (1) all-electric systems for high-efficiency electricity generation; (2) combined systems that supply energy through electricity generation as well as other forms of energy; (3) all-heat energy systems, in which no electricity is produced; and (4) total systems, which maximize the efficiency of overall energy use from source to end use.

Work is under way in Annex 1: Common Study for Energy Cascading: Establishing Priorities for Cooperative Research and Development. Annex 2 has taken effect: Treble Rankine Cycle Project: Design Analysis Study and Establishment of an R\&D Program.

Plans are being developed for Annex 3: A Comparative Analysis of Small Combined Heat and Power Technologies.

Belgium, Canada, Germany, Japan, the Netherlands, Sweden, and the United States have expressed an interest in coordinating the demonstration of the organic Rankine cycle (ORC) bottoming system. Specifically, the United Kingdom is interested in an annex on Information Exchange in ORC Demonstrations and Canada is interested in applying an annex on Demonstration of High Temperature ORC System to gas pipelines. These new projects will be discussed at the Executive Committee meetings.

Legal Status:

Executive Committee Chairman:

\section{Participants:}

\section{U.S. Program Manager:}

Schedule of Executive Committee Meetings:
The implementing agreement was signed on March 16, 1977.

Dr. G.E. Rajakovics, Austria

Austria, Belgium, Canada, FRG, Japan, Netherlands, Sweden, Switzerland, United States. Italy and the United Kingdom are interested in signing the agreement.

Gerald S. Leighton, DOE/BCS, (202) 252-9386

April 15-16, 1980; Paris, France

September 23-24, 1980; Paris, France 


\section{ANNEX 1: \\ COMMON STUDY FOR ENERGY CASCADING: ESTABLISHING PRIORITIES FOR COOPERATIVE RESEARCH AND DEVELOPMENT}

Project Description: The objective of the project is to identify R\&D projects that could enhance the future market for advanced energy conversion technologies including (1) all-electric systems; (2) combined systems; (3) all-heat systems; and (4) total systems. The technologies under study include the treble Rankine cycle (TRC), the organic Rankine cycle (ORC) in total energy and lowtemperature applications, and the advanced combined cycle (ACC). The market for these systems is estimated using a common technical approach.

In the first phase of the study, the participants prepared a brief survey and preliminary ranking of several Rankine technologies. Specifically, each country. collected performance, economic, and technical data for each technology. The technologies analyzed were the TRC, the ACC, the ORC bottoming systems and combined heat and power systems, fuel cells, and advanced diesel combined heat and power systems.

In the next phase, the most promising technologies were analyzed in more detail, and estimates of their technical and economic feasibility and the likely market size were developed. Barriers to rapid commercialization were identified in each country. This in-depth analysis has been completed for the TRC, the ACC, the ORC combined heat and power system, and ORC bottoming systems. The final report on the common study has been approved by the Executive Committee and will be distributed in mid-1980.

Legal Status:

Operating Agent:

\section{U.S. Program \\ Manager:}

Project Financing:
The annex took effect on March 16, 1977 (duration: 2 years) .

United States

Gerald S. Leighton, DOE/BCS, (202) 252-9386

The project was funded jointly as follows:

$\begin{array}{lr}\text { Austria } & \$ 10,850 \\ \text { Belgium } & 19,560 \\ \text { Canada } & 55,343 \\ \text { Germany } & 135,350 \\ \text { Japan } & 189,909 \\ \text { Netherlands } & 25,050 \\ \text { Sweden } & 20,750 \\ \text { Switzerland } & 18,800 \\ \text { United States } & 215,450\end{array}$




\section{ANNEX 2: \\ TREBLE RANKINE CYCLE PROJECT: \\ DESIGN ANALYSIS STUDY AND \\ ESTABLISHMENT OF AN RED PROGRAM}

Project Description: The objective of the project is to specify in detail the cost and technical problems associated with the treble Rankine cycle to provide a sound basis for decisions about developing components and additional technological work. The treble Rankine cycle consists of three energy conversion processes using potassium, diethyl, and water as working fluids. The final step would be to specify a research program to address the more significant problems.

Legal Status:

The annex took effect in July 1979 (duration: 2 years)

Lead Country:

Participants:

Project Financing:

Schedule of Working Meetings:
Germany, Kernforschungsanlage, Julich

Austria, FRG, Netherlands; the United Kingdom may join

The project is jointly funded

March 6, 1980; Stuttgart, Germany. 


\section{PLANNED ANNEX 3: \\ A COMPARATIVE ANALYSIS ÖF SMALL COMBINED HEAT AND POWER TECHNOLOGIES}

Project Description: The objective of the study is to conduct a comparative technical evaluation of a select set of small (i.e., under $25 \mathrm{MW}$ ) combined heat and power technologies. The study will characterize such technologies, specify the load curves in-important applications; identify the combined heat and power technologies that best suit each application le.g., industrial, commercial, residential, agricultural), estimate the market tor these technologies, and specify the R\&D projects that could remove barriers to the implementation of the most promising technologies.

Legal Status:

Lead Countries:

Interested Countries:

U.S. Program

Manager:

Project Financing:

Schedule of

Working Meetings:
A draft of the annex is being circulated to interested countries.

Canada and Belgium.

Belgium, Canada, FRG, Italy Japan, Netherlands, Sweden; Switzerland, United States

1 To be determined

The project will be funded on a task-sharing basis.

April, 1980; Paris, France 


\section{Heat Pumps with Thermal Storage}

Project Area Objectives: The objectives of this project are to conduct the theoretical and experimentai development programs on heat pump systems, and to establish a central collection, collation, and distribution center for the exchange of information on heat pumps with thermal storage capabilities. The project will be limited to heat pump systems with thermal storage, for generating domestic space heating and cooling and water heating through the compression cycle.

The heat pump executive committee is primarily an information-sharing venture at this point. Each contracting party is assuming responsibility for a project relating to demonstration of a heat pump system with thermal storage.

Work is under way in Annex 1: Heat Pump Systems with Thermal Storage

Legal Status:

Executive Committee Chairman:

\section{Participants:}

\section{U.S. Program Manager:}

Schedule of Executive Committee Meetings:
The implementing agreement was signed in March 1977. New annexes will be pursued under the advanced heat pump agreement

Mr. Steen Rolf Jacobsen, Denmark

Austria, Denmark, FRG, Ireland, Italy, Netherlands, New Zealand, Sweden, Switzerland, United States

John Ryan, DOE/BCS, (202) 252-9130

February 25-26, 1980; Vienna, Austria (joint meeting with Advanced Heat Pumps participants). 
ANNEX 1:

HEAT PUMP SYSTEMS WITH THERMAL STORAGE

Project Description: The project is designed as an information-sharing vehicle. Each nation is responsible for an experimental demonstration of a heat pump system with thermal storage, with the exception of Denmark, which is fulfilling its responsibilities by evaluating all projects and preparing and publishing reports.

This project is limited to heat pump systems with thermal storage for the generation of heat for nonindustrial purposes, such as domestic space and water heating, using the compression cycle.

The U.S. project is designed to demonstrate the capability of the annual cycle energy system (ACES) at Oak Ridge National Laboratory, Oak Ridge, Tennessee. The principal component of this system is an insulated tank of water which serves as a thermal storage bin. In winter, heat is obtained by a heat pump, which also turns the water in the bin into ice over a period of months. In summer, the chilled water is used to provide air conditioning without the operation of the heat pump compressor.

Work on this project has been completed, and the final report will be issued in May 1980.

Legal Status:

Operating Agent:

Participants:

U.S. Program
Manager:

Project Financing:

Schedule of Working Meetings:
The annex took effect on March 16, 1977 (duration: 3 years)

\section{Austria}

Austria, Denmark, FRG, Ireland, Italy, Netherlands, New Zealand, Sweden, Switzerland, IJnited States

John Ryan, DOE/BCS, (202) 252-9130

The project is financed on a task-sharing basis with each country assuming its own expenses

January 15, 16, 1979; Paris, France

February 25, 1980; Vienna, Austria. 


\section{Advanced Heat Pumps}

Project Area Objectives: The objective of this project is twofold: to facilitate the exchange of information on electric and thermally activated heat pumps among participants and to undertake cooperative research, development, and demonstration work in these areas. Previous work, which was completed under the original Heat Pumps with Thermal Storage Implementing Agreement, identified new RDED cooperative projects that will be pursued under this implementing agreement.

Work is under way on Annex 1: Common Study of Advanced Heat Pump Systems and a second annex is planned: Development of Vertical Sub-Soil Heat Source System for Heat Pumps. Also under discussion is the establishment of an IEA Heat Pump Center and the integration of large heat pumps into district heating. The participants have expressed interest in pursuing several other annexes dealing with: low-cost sorption heat pump systems, development of heat-activated drives for heat pumps, application of heat pumps in industry, and examination of advanced heat source equipment.

Legal Status:

\section{Executive Committee Chairman}

Participants:

\section{U.S. Program ' Manager:}

Schedule of Executive Committee Meetings:
The implementing agreement was signed in July 1978. It is an extension of the Heat Pump with Thermal Storage implementing agreement, to which no new annexes can be added.

Torbjorn Borstrom, Sweden

Austria, Belgium, Canada, Denmark, FRG, Italy, Japan, Netherlands, Spain, Sweden, Switzerland, United Kingdom, United States

John Ryan, DOE/BCS (202) 252-9130

February 27-28, 1980; Vienna, Austria June 12-13, 1980; Paris, France 


\section{ANNEX 1: \\ COMMON STUDY OF ADVANCED HEAT PUMP SYSTEMS}

Project Description: The objectives of this project are to collect and assess data on the current state of the art for advanced heat-activated heat pumps internationally, and to study the residential market potential for the technology in all participating countries. The advanced systems under study include absorption heat pumps and various chain-driven designs. The Federal Republic of Germany is performing the technical portion of the study; the United States is performing the market portion.

The results of the technical and market studies will be used to recommend additional R\&D activities, to overcome technical barriers, and to increase the market potential of advanced heat pump systems. Information has been collected on 20 different heat pump system types in 13 countries. The study will be completed by June, 1980.

Legal Status

Operating Agent:

Participants:

U.S. Program

Manager:

Project Financing:
The annex took effect on July 27, 1978 (duration: 2 years or until Executive Committee terminates).

Federal Republic of Germany, Kernforschungsanlage, Julich

Austria, Belgium, Canada, Denmark, FRG, Italy, Japan, Netherlands, Spain, Sweden, Switzerland, United Kingdom, United States

John Ryan, DOE/BCS, (202) 252-9130

The project is jointly funded as follows (deutschemarks):

Austria

Belgium

Canada

Denmark

FRG

Italy

Japan

Netherlands

Spain

Sweden

Switzerland

United Kingdom

United States
43,810

87,620

21,905

400,000

87,620

175,240

43,810

43,810

43,810

43,810

87,620

400,000

Schedule of Working

February 27, 1980, Vienna, Austria

Meetings:

June 12-13, 1980; Paris, France 


\section{PLANNED ANNEX 2:}

DEVELOPMENT OF VERTICAL SUB-SOIL HEAT SOURCE SYSTEM FOR HEAT PUMPS

Project Description: The objective of this project is to collect and evaluate the data obtained by various countries on vertical sub-soil heat source systems for heat pumps, to assess the systems' market potential, and to recommend future R\&D programs for these systems. The study will focus on two major aspects: technology survey and market potential assessment.

Legal Status:

Lead Country:

Participants:

Project Financing:

Schedule of Working Meetings:
The annex is in the planning stage; definitive action will take place at the June meeting

Sweden

The United States is interested in the project

The project will be jointly funded

February 27-28, 1980; Vienna, Austria

June 12-13; Paris, France 


\section{THIS PAGE}

\section{WAS INTENTIONALLY \\ LEFT BLANK}




\section{Combustion}

Project Area Objectives: Energy Conservation in Combustion was established as a separate project area to improve the energy efficiency of combustion technologies and develop the fuelswitching capability of combustion equipment. The major objective of this project area is to concentrate on improving the information, instrumentation, and calculating procedures used by the designers, users, and fabricators of engines and furnaces. Work has been completed in one area, Annex 1. Energy Conservation in Combustion. A new implementation agreement has been drafted and will be signed by July 1980 . Future annexes will be pursued under this new agreement.

\section{Legal Status:}

\section{Executive Committee Chairman:}

\section{Participants:}

U.S. Program

Manager:

Schedule of Executive Committee Meetings:
The implementing agreement was signed on March 16, 1977 (duration: 3 years)

Dr. Philip Hutchinson, AERE, Harwell, United Kingdom

Italy, Sweden, United Kingdom, United States

Karl Bastress, DOE/ACT (202) 376-9154

July 10-11, 1980; Paris, France. 


\section{ANNEX 1: ENERGY CONSERVATION IN COMBUSTION:}

Project Description: This project consists of cooperative R\&D and information exchange among participating countries in three areas related to engine and furnace technology: (1) combustion system modeling. (2) instrumentation and studies of fundamental processes in combustion, and (3) resource exchange. Fourteen tasks are being conducted within these three project areas.

Research in combustion system modeling is directed toward developing combustion technology codes for engines and furnaces. In the work related to fundamental processes in combustion, participants are developing insliuments and experimental techniques to measure fundamental parameters and properties of combustion systems and various fuels, and to investigate the basic physical phenomena relevant to the combustion process. The purpose of the resource exchange area is information exchange among the contracting parties on the numerical analysis methods, laboratory analysis, objectives and results of past programs, and experimental test facilities.

Currently, the United States is conducting five tasks under this annex:

- Experimental methods for measurements in internal combustion engines. This task involves the measurement of turbulence levels, velocity fields, species concentrations, densities, temperatures, and equivalence ratios in an injected engine, using laser Raman spectroscopy and laser Doppler anemometry. The 1979 research program addressed fuel-injected high-swirl engines and the use of a pulsed-laser system for precision measurements. The experimental methods that are developed and applied will constitute a data base on combustion. This data base will include information on the turbulence, velocity fields, fuel-air distribution, and temperature within the combustion chambers of operating engines (primarily direct injection stratified charge engines).

- Numerical modeling of internal combustion engine performance. This task involves developing computer models of swirling combustion in two-dimensional engine configurations. A new procedure, developed to predict spray droplet transport, requires significantly less computer storage.

- LDA measurement of velocities in time-varying flows. This task resulted in the development - of a backscatter LDA system for measuring velocities and turbulence intensities dependent on crank position in internal combustion engines. The system is currently being perfected.

- Raman spectroscopy for remote measurement of temperature and concentration. The United States is developing a number of laser Raman systems for measuring local temperatures and species concentrations in combustion systems. These laser systems are currently being tested.

- Resource analysis and exchange. Under this task, the United States has conducted a detailed survey of the technical characteristics of combustion research facilities in the United States and Europe. A series of abstracts on the survey has been widely circulated. 
Legal Status:

Operating Agent:

Participants:

U.S. Program

Manager:

Project Financing:
The annex took effect on March 16, 1977 (duration: 3 years). A new implementing agreement will be signed by July 1980 .

United States, Department of Energy

Italy, Sweden, United Kingdom, United States

Karl Bastress, DOE, ACT (220) 376-9154

The project is financed on a task-sharing basis. 
THIS PAGE

\section{WAS INTENTIONALLY}

LEFT BLANK 


\section{Heat Transfer and Heat Exchangers}

Project Area Objectives: The participants in the heat transfer and heat exchangers project are seeking, through cooperative R\&D and information exchange, to improve the design and operation of heat transfer systems, particularly heat exchangers, to conserve fuel. The specific objectives of the project are to: (1) increase the efficiency of energy conversion systems by developing more effective heat transfer components; (2) reduce energy losses in processes by facilitating the operation of inexpensive heat exchange systems at reduced temperature differences.

Work is under way in three annexes: Annex 1: Extended Surface Heat Transfer; Annex 2: The Optimal Design of Heat Exchanger Networks; and Annex 3: Heat Exchanger Tube Vibration.

At present the United States is participating only in Annexes 1 and 3, and is likely to participate in Annex 2 under the new Heat Transfer and Heat Exchangers Implementing Agreement (draft). An additional annex dealing with enhanced surfaces to recover low-grade waste heat is under consideration by the Executive Committee.

Legal Status:

\section{Executive Committee Chairman:}

Participants:

\section{U.S. Program Manager:}

Schedule of Executive Committee Meetings:
The implementing agreement was signed in June 1977 (duration: 3 years); a new implementing agreement is being drafted and should be signed in September, 1980

Dr. G.F. Hewitt, United Kingdom

Sweden, Switzerland, United Kingdom, United States

Karl Bastress, DOE, Energy Conversion and Utilization Technology Branch (202) 376-9154

Bill Thielbahr, DOE, Idaho Operations Office (208) 526-0682

April 29-30, 1980; National Engineering Laboratory, 'Glasgow, Scotland, U.K.

April 22-24, 1981; Switzerland 
ANNEX 1:

EXTENDED SURFACE HEATING TRANSFER

Project Description: The objectives of this project are as follows:

- To use modern, experimental, and analytical techniques to gain a better fundamental understanding of extended surface heat transfer.

- Candidate techniques include laser anemometry, infrared thermometry, holographic methods, turbulent flow modeling methods, and numerical solutions of the conjugated, conduction, and convection problems.

- To produce new data on extended surface systems, allowing better system design. These data would include not only heat transfers and pressure drop data, but also data on operational problems such as humidity, icing, particulate fouling and pulsations.

: To attempt to develop new forms of extended surface systems, bearing in mind their applications and the problems of manufacturing particular surfaces.

In this annex, Sweden is conducting experimental and theoretical studies of conjugated, convection, and conduction problems, including infrared measurement of temperature distributions along candidate extended surfaces. The United Kingdom is: 1) conducting studies of the performance of heat pumps under frosting conditions; 2) evaluating impact of fouling on industrial energy usage; and 3) experimentally evaluating fouling mechanisms and the performance of extended surfaces in a wind tunnel that allows injection of industrial dust. The United States is conducting an experimental project to determine acid corrosion and fouling of extended heat exchanger surfaces in the exhaust stream of large diesel engines. This U.S. effort focuses on determining diesel exhaust composition, acid-corrosion resistant materials, fouling and corrosion patterns of extended surfaces, and performance of a full-scale heat exchanger in a diesel-exhaust stream. Switzerland is conducting analytical and experimental optimization investigations at twintube, gas-liquid heat exchangers for cooling power applications. The Netherlands is performing experimental work on the frosting of extended surfaces for heat pump applications.

Legal Status: $\quad$ The Annex took effect on June 28, 1977

Operating Agent: United Kingdom, Atomic Energy Authority

Participants: $\quad$ Sweden, Switzerland, United Kingdom, United States

U.S. Program Karl Bastress, DOE (202) 376-9154

Managers: $\quad$ Bill Thielbahr, DOE Idaho Operations Office (208) 526-0682

Project Financing: This project is funded on a task-sharing basis

Schedule of Working April 29-30, 1980; Scotland, U.K.

Meetings: April 22-24, 1980, Switzerland 


\section{ANNEX 2:}

THE OPTIMAL DESIGN OF HEAT EXCHANGER NETWORKS

Project Description: Thc objectives of this project are to:

- Develop a better understanding of the various optimization methods used to design heat exchanger networks

- Promote a more widespread use of these techniques in the industry

- Further develop the state of the art on optimization of thermal design through appropriate $R \& D$ efforts.

Sweden is collecting information on industrial applications of these methods and identifying suitable case studies. The United Kingdom is identifying various optimization techniques and also collecting information for development of case studies. The United States, upon joining this Annex will select the optimum method and exploit it in the U.S.

Legal Status:

Operating Agent:

Participants:

U.S. Program

Manager:

Project Financing:

Schedule of Working Meetings:
The annex took effect on June 28, 1977 (duration: 3 years)

United Kingdom, Atomic Energy Authority

Sweden, Switzerland, United Kingdom; the U.S. is interested in joining.

Karl Bastress, DOE (202) 376-9154

This project is funded on a task-sharing basis.

April 29-30, 1980; National Engineering Laboratory, Scotland, U.K. April 22-24, 1981; Switzerland 


\section{ANNEX 3: HEAT EXCHANGER TUBE VIBRATION}

Project Description: The objectives of this project are to:

- Develop an understanding of the mechanisms of tube vibrations within heat exchangers, leading to calculation methods for idealized cases

- Consider in detail the application of fundamental methods for predicting vibration in actual heat exchanger configurations

- Confirm the applicability of predictive methods in field and other large-scale tests

- Develop a data bank of actual heat exchanger/tube vibration cases.

In this area, Sweden is working on turbulent buffeting and interaction between turbulent-flow field and cylinders in cross-flow. Switzerland is studying vortex shedding in tube-bank heat exchangers. The United Kingdom is working on the effect of tube layout on fluid-elastic whirling. The United States is developing the data bank and building a full-sized heat exchanger that will provide detailed measurements of tube vibration. The preparations for this test and the design of the experiment have been completed; testing started in 1979 .

Legal Status:

Operating Agent:

Participants:

\section{U.S. Program Manager:}

Project Financing:

Schedule of Working Meetings:
The annex took effect on June 28, 1977 (duration: 3 years)

United Kingdom, Atomic Energy Authority

Sweden, Switzerland, United Kingdom; the United States is interested in joining.

Karl Bastress, DOE (202) 376-9154

This project is funded on a task-sharing basis

April 29-30, 1980; National Engineering Laboratory, Scotland, U.K. April 22-24, 1981; Switzerland 


\section{Energy Storage}

Project Area Objectives: Under this project, participants will perform and compare preliminary design studies of a variety of experimental and advanced energy-storage technologies. The Executive Committee is working to determine which systems are suitable for demonstration projects that will lead to the widespread use of energy-storage techniques. Participating countries are exchanging funds, personnel, and information to conduct the projects.

Work is being performed in Annex 1 and Annex 2. Annex 1: Large-Scale Thermal Storage Systems; Annex 2: Lake Storage Demonstration in Mannheim, Germany.

In addition, several new annexes are being developed. Belgium has prepared a draft annex on small storage systems. Denmark, the EEC, the Netherlands, Germany, Switzerland, and the United States have expressed some interest in participating in such an annex. Sweden has prepared a draft annex on hydrated hydrogen storage. In addition, electrochemical storage and flywheels have been suggested as subjects for future annexes. The United States has circulated a letter asking for information on current activities and suggesting a list of projects to be considered at the April 1980 meeting.

Legal Status:

\section{Executive Committee Chairman:}

Participants:

\section{U.S. Program \\ Manager:}

Schedule of Executive Committee Meetings:
The implementing agreement was signed on September 22, 1978

Dr. George F. Pezdirtz, U.S. Department of Energy

Belgium, Denmark, FRG, Sweden, Switzerland, United States, the European Economic Community

Dr. George F. Pezdirtz, DOE/ACT, (202) 376-9287

April 29-30, 1980; Mons, Belgium 


\section{ANNEX 1: \\ LARGE-SCALE THERMAL STORAGE SYSTEMS}

Project Description: This project is a cooperative effort to study a variety of experimental and advanced energy-storage technologies, including aquifers for electricity storage, geothermal systems, batteries, and reactive chemistry. The first objective of this task is to undertake preliminary design studies of a variety of large-scale, low-temperature thermal storage systems. The second objective is to carry out comparative technical and economic evaluations of the design studies, and to select at least one for a proposed, jointly funded hardware demonstration project.

The work of the participating countries is under way, and should be completed by mid- 1980 .

Legal Status:

Operating Agent:

Participants:

U.S. Program Manager:

Project Financing:

Schedule of Working Meetings:
The annex took effect on September 22, 1978

Switzerland, Universite de Neuchatel, Centre d'Hydrogeologie

Belgium, Denmark, Germany, Sweden, Switzerland, United States, and European Economic Community

Dr. George F. Pezdirtz, DOE/ACT, (202) 376-9287

The project is funded on a task-sharing basis

June 19-20, 1980; Copenhagen, Denmark. 


\section{ANNEX 2: \\ LAKE STORAGE DEMONNSTRATION IN MANNHEIM, GERMANY}

Project Description: The objective of this project is to obtain operational experience in the construction and operation of a large-scale, insulated; artificial body of water in which waste heat is stored for seasonal use. The insulated storage lake is located in the city of Mannheim, Germany, and has a capacity of 30,000 cubic meters. Emphasis will be placed on research questions such as construction techniques, removal of rainwater, charging and discharging facilities, temperature stratification, and long-term material studies. Modifications to the original work plan were recently announced by Germany. Construction plans have been terminated and the program participants are currently discussing recommendations on how to proceed.

Legal Status: _ . The annex was signed in May 1979:

Lead Country: Germany

Participants: . Denmark, Germany, Sweden, United States. The Netherlands and Japan are interested in joining.

Project Financing: The funding of this project is on a joint basis as follows (deutschemarks):

Denmark

Germany

Netherlands

Sweden

United Statés

Total

March 25, 1980; Mannheim, Germany.
Schedule of Working Meetings:

$$
\begin{array}{r}
100,000 \\
8,500,000 \\
200,000 \\
200,000 \\
1,000,000 \\
10,000,000
\end{array}
$$




\section{THIS PAGE}

WAS INTENTIONALLY

\section{LEFT BLANK}




\section{Cement Manufacture}

Project Area Objectives: This project provides for cooperative RD\&D and exchange of information among the participating countries. on energy conservation in cement manufacture. Initial areas of study are kiln research, blended cements, sulfate specifications, possible gypsum substitutes, and alkali-aggregate reaction research.

Work is under way in one annex, Annex 1: Energy Conservation in Cement Manufacture.

Legal Status:

\section{Executive Committee}

Chairman:

Participants:

\section{U.S. Program}

Manager:

Schedule of Executive Committee Meetings:
The implementing agreement was signed in July 1978.

Dr. B. Warris, Sweden

Germany, New Zealand, Sweden, United Kingdom, United States

Mr. A.J. Streb, DOE/INDUS, (202) 252-2098

March 11-13: Washington State, U.S.A. 


\section{ANNEX 1:}

\section{ENERGY CONSERVATION IN CEMENT MANUFACTURE}

Project Description: The objectives of the program are to:

- Increase the efficiency of energy use in cement manufacture

- Reduce the use of premium fuels in cement manufacture by permitting increased use of highsulfur fuels, particularly high-sulfur coals

- Reduce the amount of energy needed to produce high-quality concrete.

The R\&D program that has been undertaken to date includes a number of products that fall into four basic areas:

- Kiln research

- Blended cements

- Sulfate specifications and possible gypsum substitutes

- Alkali-aggregate reaction research.

Legal Status:

Operating Agent:

- Participants:

- U.S. Program Manager:

Project Financing:

Schedule of Working Meetings:
The annex took effect in July 1978.

United States, Department of Energy

Germany, New Zealand, Sweden, United Kingdom, United States

Mr. A.J. Streb, DOE/INDUS (202) 252-2098

The project is funded on a task-sharing basis.

March 11-13, 1980; Portland Cement, Washington State, U.S.A. 


\section{High-Temperature Materials for Automotive Propulsion Systems}

Project Area Objectives: An expert group in transportation has been formed to study applications of high-temperature materials in automotive gas turbine, diesel, and Stirling engines. The group will concentrate particularly on high-temperature structural ceramics.

Annex 1: Investigation of Ceramic Material Properties is under way to support a ceramic components program for vehicular gas turbine engines in each of the participating countries. A second annex, Definition of Experimental Material Characterization Methods, is in the draft stage.

Legal Status:

Executive Committee Chairman:

\section{Participants:}

\section{U.S. Program Manager:}

Schedule of Executive Committee Meetings:
The implementing agreement was signed on May 22, 1979

Robert Schultz, U.S. Department of Energy

FRG, United States; Sweden intends to sign.

Robert Schultz; DOE/TEC (202) 252-8064

April 14-18, 1980; Dearborn, Michigan, U.S.A. November 26, 1980; Bonn, FRG 


\section{ANNEX 1: INVESTIGATION OF CERAMIC MÁATERIAL PROPERTIES}

Project Description: The objective of this project is to organize and carry out investigations of high-temperature structural ceramics for automotive (including cars, trucks, and buses) gas turbine engine applications, with emphasis on materials and component technology.

The agreement contains the following subtasks:

1. Technical information exchanye

2. Investigation of ceramic materials' properties

3. Exchange of life estimates techniques and results for critical components

4. Nondestructive evaluation of ceramic materials.

Legal Status:

Operating Agent:

Participants:

\section{U.S. Program}

Manager:

Project Financing:

Schedule of Working Meetings:
The annex took effect in May 1979 (duration: to the end of December 1980, or until Executive Committee terminates)

\section{U.S. Department of Energy}

FRG, United States: German Aerospace Research Establishment (DFVLR) and U.S. DOE. Sweden, Japan, and Italy have expressed interest in participating.

Robert Schultz, DOE/TP (202) 252-8064

This project is financed on a task-sharing basis

April 16, 1980; Dearborn, Michigan; 5th International Symposium on Automotive Propulsion Systems.

November 26, 1980, Bonn, FRG

November 24-26, 1980, Bad Neuenahr, FRG; Ceramic Components Program for Vehicular Gas Turbine Status 


\section{PLANNED ANNEX 2: \\ DEFINITION OF EXPERIMENTAL MATERIAL CHARACTERIZATION METHODS}

Project Description: The objectives of this project are to evaluate current experimental methods for characterizing materials that are applicable to high-temperature structural ceramics for automotive gas turbine and Stirling engines; the project will also recommend experimental studies to remedy deficiencies in the data base.

The evaluation will include mechanical and thermophysical properties, high-temperature creep behavior, fracture toughness, slow crack growth, and environmental resistance.

The recommendations will include a definition of specific data required, recommended test procedures, and recommended data analysis methods.

Legal Status:

Lead Country:

Interested Countries:

\section{U.S. Program}

Manager:

Estimated Maximum U.S. Involvement:
The annex is in the draft stage.

United States (Corning Glass)

FRG, Japan, Sweden, United States

Robert Schultz, DOE/TEC (202) 252-8064

This project will be financed on a task-sharing basis. 


\section{THIS PAGE WAS INTENTIONALLY LEFT BLANK}




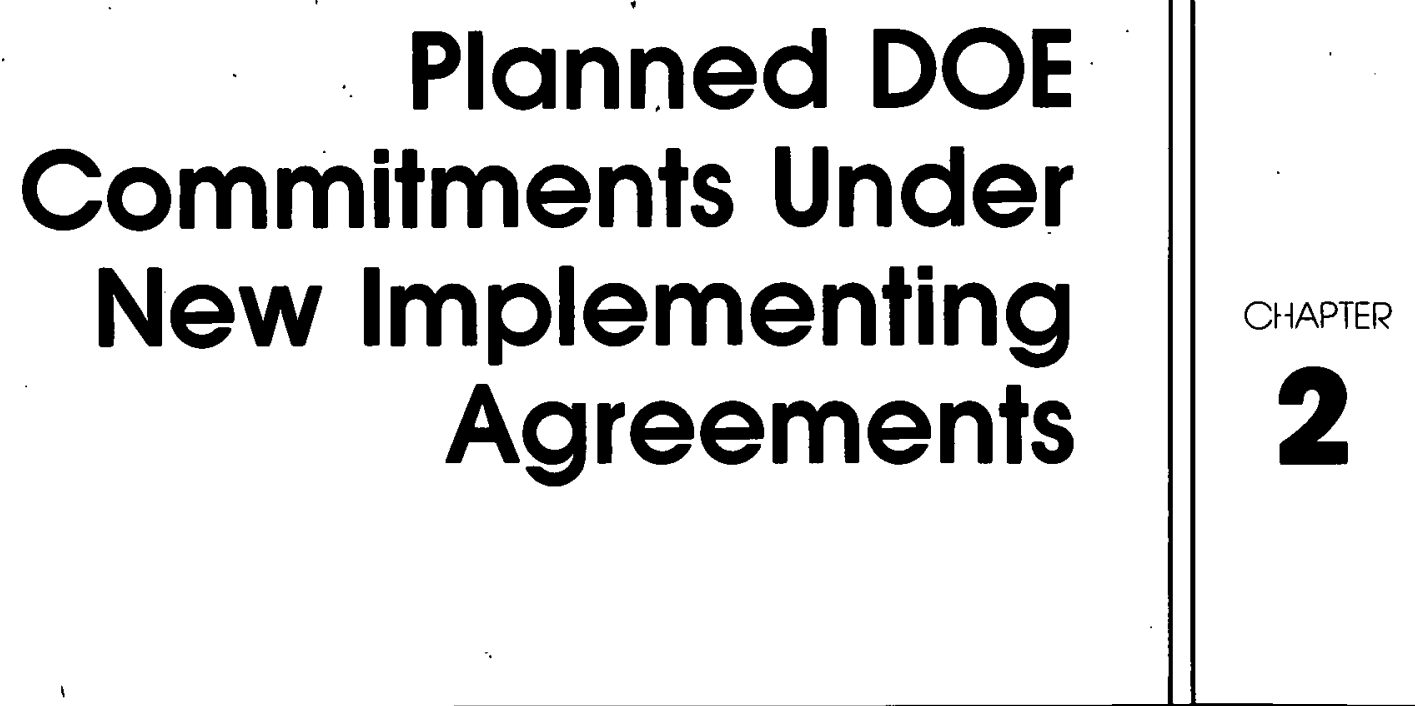


In addition to its current commitments, DOE has been discussing the initiation of implementing agreements with other IEA member nations in six other project areas:

- Combustion (extension of current agreement)

- Pulp and Paper

- Iron and Steel

- Food Processing

- Urban Waste

- Alcohol Additives to Fuels

DOE is planning to make commitments to all but one of these new agreements. Nine annexes are currently being considered in these project areas; DOE has taken the lead in two, and indicated interest in three more (see Exhibit 3). 
Exhibit 3

Countries Interested in Planned Implementing Agreements

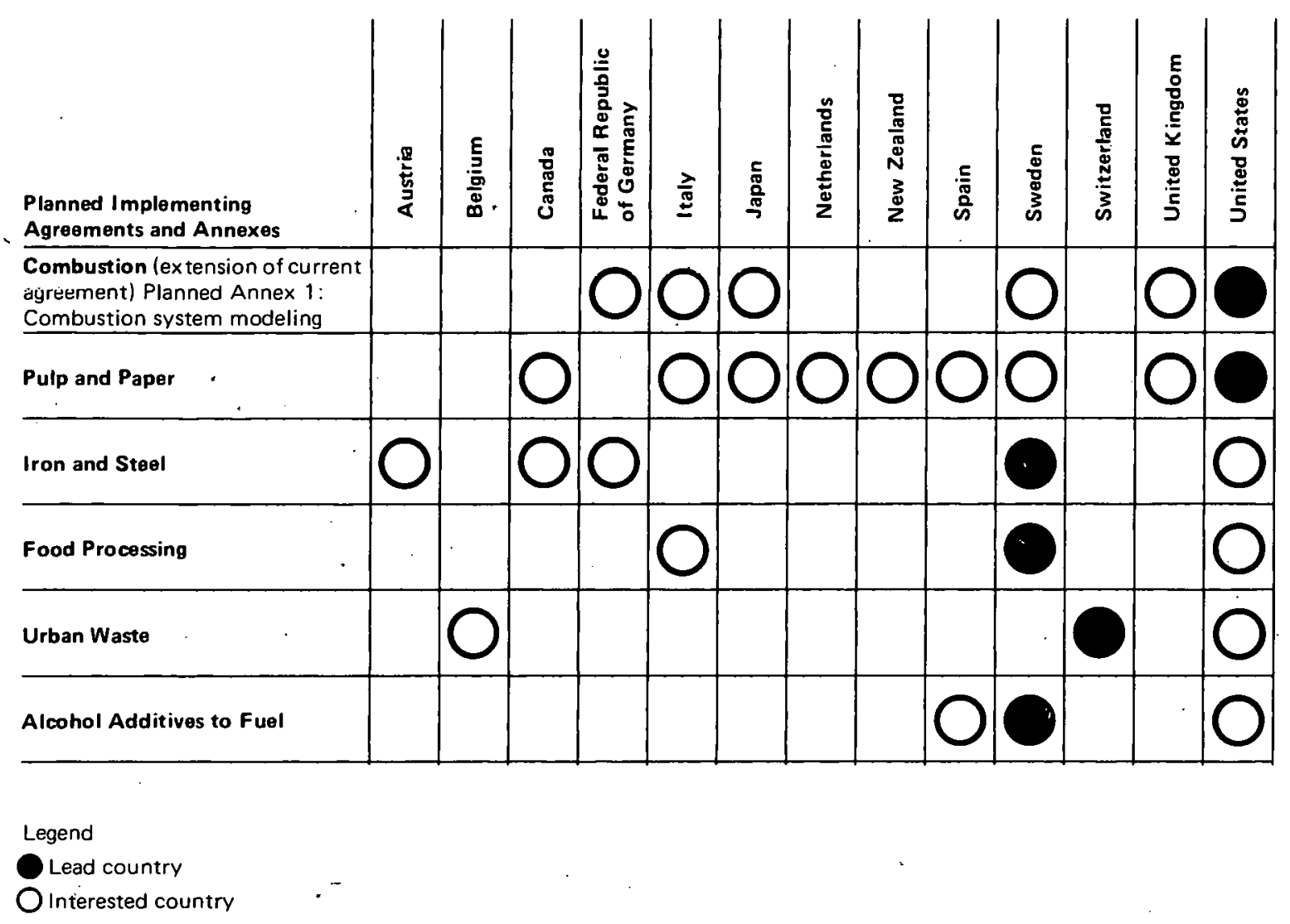


THIS PAGE

\section{WAS INTENTIONALLY \\ LEFT BLANK}




\section{Combustion}

Project Area Objectives: The objective of the planned implementing agreement is to accelerate the development of new combustion equipment that is more efficient, less polluting, and capable of using alternative fucls. The efforl has been planned to improve the calculation procedures used by the designers, users, and manufacturers of combustion equipment.

Annex 1: Combustion System Modeling was initially drafted in November 1978. It concentrates on three areas: (1) advanced pistun engine technology, (2) furnaces and boilers, and (3) fundamentals and supporting activities.

\section{Legal Status:}

Lead Country:

Interested Countries:

\section{U.S. Program \\ Manager:}

Scheduled Executive Committee Meetings:
The implementing agreement will be signed in July 1980, replacing the previous combustion agreement

\section{United States}

Italy, Sweden, United Kingdom, United States. The FRG and Japan hope to get involved.

Dr. E. Karl Bastress, DOE/ACT (202) 376-9154

July 10-11, 1980; Paris, France

September 1980; Sandia Laboratories, Livermore, California, U.S.A. 


\section{PLANNED ANNEX 1:} COMBUSTION SYSTEM MODELING

Project Description: The combustion project involves, tasks in experimental and computational areas. The project will emphasize the application of tools to produce codes, together with supporting data bases. These codes will be used by industry to predict performance of advanced com-. bustion equipment. The United States will be involved in the following areas:

(1) Advanced piston engine technology: The objective of this area is to jointly develop combustion technology, both analytical and experimental, which will provide improved models (e.g., data bases and system codes) for advanced internal combustion piston engines, such as open-chamber stratified charge, divided-chamber stratified charge, and diesel engines.

(2) Furnaces and boilers: The objective of this area is to jointly develop combustion technology, both analytical and experimental, which will provide improved models le.g., data bases and system codes) for furnaces and boilers.

(3) Fundamentals and supporting activities: The objective of this area is to provide necessary instrumentation and analytical and administrative support for programs in Areas 1 and 2, and to support investigations of new combustion techniques.

Legal Status: $\quad$ The annex will take effect in July 1980

Lead Country: $\quad \cdot$ United States

Interested Countries: Italy, Sweden, United Kingdom, United States

U.S. Program Dr. E. Karl Bastress, DOE/FFU (202) 252-9154

Manager:

Estimated Maximum The project will be funded on a task-sharing basis:

U.S. Involvement: Italy $\quad \$ 400,000$

Sweden $\quad 330,000$

$1 \quad$ United Kingdom $\quad 260,000$

Schedule of October 8-9, 1980; Sandia Laboratories, Livermore, California, U.S.A.

Working Meetings: 


\section{Pulp and Paper}

Project Area Objectives: Interest has been indicated in cooperative research and information exchange on energy conservation in: (1) pulping and bleaching, (2) energy recovery and generation, (3) materials recovery, (4) paper making and drying, (5) coating and converting, and (6) energy management. A final draft of the agreement and proposed annexes has been circulated.

Legal Status:

Lead Country:

Interested Countries:

U.S. Program Manager:
The implementing agreement will be signed in mid-1980.

United States

Belgium, Canada, Finland, Japan, Netherlands, New Zealand, Norway, Spain, Sweden, United Kingdom, United States

Mr. A.J. Streb, DOE/INDUS (202) 252-2098 


\section{ANNEX 1: \\ INCREASING THE THERMAL EFFICIENCY OF KRAFT RECOVERY BOILERS}

Project Description: For economic and environmental reasons, it is normal for kraft pulp mills to burn concentrated spent liquor from draft production in a recovery boiler in order to produce steam or electricity, or both. Under present methods, however, the dry-solids convent of spent liquor is limited to concentration levels of less than 65 percent. This limitation of dry-solids content results, in turn, in a decrease in the energy available for steam generation. The objective of this project will be to investigate alternative methods of obtaining concentrated waste liquids, thereby increasing the overall energy efficiency of recovery boiler operations.

Legal Status:

Interested Countries: Sweden, United States

\section{U.S. Program Manager:}

Estimated Maximum U.S. Involvement: mid-1980...

United States
The annex is in draft form, awaiting final approval; it will take effect in

Mr. A.J. Streb, DOE (202) 252-2098

The project will be funded on a task-sharing basis:

Sweden
$\$ 600,000$
$\$ 1,000,000$ 


\section{ANNEX 2: \\ DETERMINING THE ENERGY REQUIRED BY THE FUNCTIONS OF SPECIFIC GRADES OF PAPER AND PAPER BOARDS}

Project Description: The energy intensity, of paper production is related to the quality of the product. The manufacture of paper and paperboard of a quality not exceeding functional requirements may result in considerable energy savings. The objective of this project is to determine the energy consumed in the manufacture of the major bulk-type paper and paperboard products, and to develop quantitative methods of simulating trends in the products' overall energy consumption vis-a-vis product quality and function requirements. The accounting system of Annex 3 will be used to calculate the energy required to produce the designated quality grades.

Legal Status:

Lead Country:

Interested Countries:

Project Financing:
The annex is in draft form and awaiting final approval.

Finland

Finland, Norway, Spain, Sweden

The project will be funded on' a task-sharing basis 


\section{ANNEX 3: \\ DEVELOPING AN ENERGY ACCOUNTING METHOD FOR THE PULP AND PAPER INDUSTRY}

Project Description: In order to compare the relative energy efficiency of products and processes in the pulp and paper industry, it is necessary to collect statistical data on energy consumption and production. Because of differences in the energy accounting systems of countries, industries, institutions, and individuals, it is difficult to make meaningful comparisons or draw conclusions about data. The objective of this project is to develop a uniform, internationally accepted method of measuring and calculating energy usage in the pulp and paper industry at the process, department, and mill levels. To do this, a uniform measure for calculating the energy content of a given product must be developed.

Legal Status:

Lead Country:

Interested Countries: Belgium, Finland, Japan, Netherlands, Spain, Sweden, United Kingdom, United States

\section{U.S. Program}

Manager:

Estimated Maximum U.S. Involvement:

The annex is in draft form and no final decision has been made on approval

Sweden

Al Streb, DOE/INDUS (202) 252-2098

The project will be funded on a joint basis as follows: (Swedish kronor)
Belgium

44,000

Finland

Japan

44,000

176,000

Netherlands

44,000

Spain

Sweden

44,000

U.K.

44,000

88,000

U.S. 


\section{ANNEX 4: \\ IMPROVING ENERGY CONSERVATION IN MECHANICAL DEFRIBRATION, BEATING, AND WATER REMOVAL}

Project Description: Wood defribration, beating, and water removal are three of the most energy-intensive processes in the pulp and paper industry; wood defribration, for instance, requires 1,500 to $2,500 \mathrm{kWh}$ per ton of pulp. The objective of this project is to investigate energy conservation methods; techniques, or processes to reduce energy consumption during the mechanical defribration, beating, and water removal processes.

Legal Status:

The annex is in draft form and awaiting approval

Lead Country:

United States

Interested Countries: Belgium, Canada, Finland, Japan, Netherlands, Norway, Spạin, Sweden. United Kingdom is interested in participating.

\section{U.S. Program} Manager:

Estimated Maximum U.S. Involvement:
AI Streb, DOE/INDUS (202) 252-2098

The project will be funded on a task-sharing basis. The U.S. contribution will be $\$ 1,000,000$. 
THIS PAGE

\section{WAS INTENTIONALLY LEFT BLANK}




\section{Iron and Steel}

Project Area Objectives FRG has proposed a jointly funded study of iron and steel processes. Interested parties are discussing general energy questions, reduction processes, metal forming, hot inspection, and waste-heat utilization.

\section{Legal Status:}

Lead Country:

Interested Countries:

U.S: Program

Manager:
The implementing agreement is still under discussion and no draft is available yet.

Sweden

Austria, Canada, FRG, Sweden, United States

Mr. A.J. Streb, DOE/INDUS (202) 252-2098 
THIS PAGE

\section{WAS INTENTIONALLY LEFT BLANK}




\section{Food Processing}

Project Area Objectives: Areas of interest include drying and concentration, heating conservation, and preservation. Twg meetings have been held, at which annexes in the following areas were discussed: energy accounting/energy data base; application of heat pumps in the food industry; improving the energy utilization of water removal systems; solar energy application.

Legal Status:

Lead Country:

U.S. Program

Manager:

Schedule of

Working Meetings:
The annex has not yet been drafted.

Sweden, in cooperation with Denmark, Italy, Netherlands, Spain, Switzerland, United Kingdom, United States

Larry Kelso, DOE/INDUS (202) 252-2075

March 4-5, 1980; Madrid, Spain 


\section{ANNEX 1: \\ DEVELOPING AN ENERGY ACCOUNTING METHOD \\ FOR THE FOOD INDUSTRY AND \\ ESTABLISHING AN INTERNATIONAL DATA BASE}

Project Description: The objective of this project is to develop a uniform energy accounting methodology and establish an international data base for the food processing industry. Currently, it is difficult to compare the relative energy efficiencies of products and processes because of the variety of energy accounting systems in use. The participating countries will jointly undertake a three-phase investigation of selected industries, such as the meat industry, and selected unit operations, such as grain drying, as a means of developing a methodology and collecting data. This will facilitate the evaluation of existing energy conservation strategies and the development of new ones.

Legal Status:

Lead Country:

Interested Countries:

U.S. Program

Manager:

Estimated Maximum U.S. Involvement:

Schedule of Working Meetings:
The annex has been drafted and is currently under discussion by interested countries.

Sweden, in cooperation with Spain

Denmark, Italy, Netherlands, Spain, Sweden, Switzerland, United Kingdom, United States

Larry Kelso, DOE/INDUS (202) 252-2075

Not determined

March 4-5, 1980; Madrid, Spain 


\section{ANNEX 2: \\ APPLICATIONS OF HEAT PUMPS IN FOOD INDUSTRY}

Project Description: The objective of this project is to accelerate the utilization of heat pumps for the recovery and upgrading of energy in the food industry, particularly the dairy, meat, and brewing and malting industries. Each participant will be responsible for documenting and evaluating the performance, cost, and energy usage data of heat pump applications. Through the develop-: ment of case studies, institutional and economic barriers will be identified as a basis for refining future R\&D activities.

Legal Status:

Lead Country:

Interested Countries:

U.S. Program

Manager:

Estimated Maximum U.S. Involvement:

\section{Schedule of Working Meetings:}

The draft annex is under consideration.

Sweden, in cooperation with Spain

Denmark, Italy, Netherlands, Spain, Sweden, Switzerland, United Kingdom, United States

Larry Kelso, DOE/INDUS (202) 252-2075 .

Not determined

March 4-5, Madrid, Spain 


\section{ANNEX 3: \\ IMPROVING ENERGY UTILIZATION IN SYSTEMS FOR WATER REMOVAL}

Project Description: The objective of this project is to evaluate the energy and technological efficiency of selected evaporation, spray drying, and reverse osmosis systems. Participathing countries will undertake three projects on a task-sharing basis: utilization of exhaust gases from spray driers in dairies, utilization of evaporator condensates in dairies, and improvement of reverse osmosis.

Legal Status:

Lead Country:

Interested Countries:

U.S. Program

Manager:

Estimated Maximum U.S. Involvement:

Schedule of Working Meetings:
The annex has been drafted and is currently under discussion by interested countries.

Sweden, in cooperation with Spain

Denmark, Italy, Netherlands, Spain, Sweden, Switzerland, United Kingdom, United States

Larry Kelso, DOE/INDUS (202) 252-2075

Not determined

March 4-5, 1980; Madrid, Spain 


\section{Urban Waste}

Project Description: Switzerland, together with several other countries, has expressed an interest in developing an information exchange on urban waste. The objective of the planned implementing agreement is to conduct a comprehensive survey of developments in the waste sector and assess the advantages and disadvantages of using urban waste as a fuel. A market assessment would be conducted to evaluate economic constraints and facilitate the exchange of information, and a technology survey would then be made.

Legal Status: $\quad$ The proposal for an implementing agreement is under discussion, and no agreement has yet been drafted.

Lead Country:

Interested Countries:
Switzerland

Belgium, Switzerland, United States 
THIS PAGE

\section{WAS INTENTIONALLY LEFT BLANK}




\section{Alcohol Additives to Fuel}

Project Description: The objective of the planned implementing agreement is to accelerate the production and utilization of fuels with alcohol additives. Sweden and Spain have indicated an interest in compiling and comparing existing information on the production, distribution, use, and maintenance of these fuels in various fields, e.g., agriculture, transportation, industry. A comprehensive survey (including development of abstracts in R\&D and applications) could be used as a basis for identifying areas of common interest and potential IEA cooperative research.

Legal Status:

Lead Country:

Interested Countries:

Schedule of Working Meetings:
The implementing agreement is in the discussion stage.

Sweden

Spain, United States

March 6-7, 1980, Madrid, Spain 
THIS PAGE

\section{WAS INTENTIONALLY LEFT BLANK}




\section{APPENDIX A \\ Mechanisms for Establishing Implementing Agreements and Annexes}

Each year, IEA's Committee on Energy R\&D establishes priorities for its cooperative energy research programs. Each of the committee's working parties reviews ongoing implementing agreements and annexes governing individual projects, and proposes new agreements consistent with the committee's R\&D program.

In general, new implementing agreements are suggested by one country, called the lead country. which is especially interested in a project area and willing to make the effort to organize the necessary meetings between potential participants, report. to the working party, and draft preliminary agreements. The first step in establishing a new implementing agreement is to set up an ad hoc expert group, which is composed of representatives from those countries interested in the subject matter to be covered by the new agreement.

The expert group, chaired by the lead country, then meets separately from the working party to discuss the R\&D activities it would like to perform in the given subject area. The members first review research proposals and agree on the tasks they would like to carry out. They then group these tasks into projects, which are either funded on a task-sharing basis (i.e.. each country bears its own costs) or jointly funded (i.e., cash contributions are pooled and used to pay one or more organizations to carry out the work).

The expert group, with the assistance of the IEA Secretariat, then drafts an implementing agreement and a series of annexes that govern specific technical activities on one or more projects. An implementing agreement specifies:

- Objectives for the research

- Procedures for initiating specific tasks or annexes under the agreement

- Procedures for designating countries responsible for administering an annex; these countries are called Operating Agents

- Administration and finance procedures

- Legal responsibilities and insurance

- Legislative provisions

- Admission and withdrawal of contracting parties to the agreement

- Provisions on information and intellectual property (may be specified in the annexes). 
Implementing agreements do not specify the details of the research to be carried out in a given area; the expert group writes an annex for each specific project, covering:

- Detailed objectives

- Summary descriptions of specific tasks to be performed

- Responsibilities of Operating Agent and participants

- Results or products

- Funding

- Designation of the Operating Agent

- Time period during which the annex will remain in force

- Countries and organizations participating in the task.

The annex does not usually describe the project's technical approach in full detail. In some cases, a technical description is appended to the annex to provide background information to readers not familiar with the discussions of the expert group.

The expert group submits its draft implementing agreement, annexes, and any background documents to the working party for approval. Following working party approval and legal review by the IEA Secretariat, the Secretariat circulates the complete draft implementing agreement and annexes to all IEA member countries so that they may have an opportunity to participate. After comments on the draft are received, potential participants confirmed, and contracting parties designated, the Secretariat finalizes the agreement and circulates a printer's proof to contracting parties intending to sign.

Agreements are usually signed at meetings of the IEA Governing Board; they must be signed by officials designated by the governments of IEA member countries as having the legal authority to bind the contracting parties they represent. In signing the agreement, a contracting party must agree to participate in at least one annex.

Each implementing agreement is administered by an Executive Committee consisting of representatives of the contracting parties to the agreement. Often, the members of the expert group become the founding members of the Executive Committee. Any country that was not an original signatory may express its interest in joining an ongoing agreement and be invited to sign the agreement by unanimous vote of the Executive Committee.

Once the Executive Committee is formed, the project functions independently of the working party and is only required to submit a formal annual report to the Secretariat, in addition to certain required internal reports. If the Executive Committee administers an implementing agreement with more than one annex, only participants to a given annex may vote on affairs concerning that annex.

When an Executive Committee wishes to adopt a new project, one or more participants draft an annex in consultation with the Secretariat and propose it to the committee, which may suggest revisions. The annex is drafted and circulated to all nonparticipating IEA countries, who are invited to participate. After the Secretariat reviews the annex, it may be adopted by the Executive Committee. Then, those contracting parties in the agreement intending to participate in the annex notify the Secretariat. Countries not party to the implementing agreement may participate in the new annex only by first signing the agreement. 


\section{APPENDIX B \\ Working Party Members}

Chairman

Australia

Austria

Belgium

Canada

Denmark
Mr. John Millhone

Director

Buildings and Community Systems

U.S. Department of Energy

(202) 252-9444

Mr. Robert Layland

c/o Australian Delegation to OECD

4 , rue Jean-Rey

F75015 Paris, France

Professor P.V. Gilli Institut fur Dampfkesselbau,

Reaktortechnik und Waermewirtschaft

Technische Universitaet Graz

Kopernikusgasse, 24

A-8010 Graz

Tel: (316) 77511, ext. 7300

TIX: 31221

Mr. J.C. Delcroix

Services de Programmation

de la Politique Scientifique

Rue de la Science, 8

B-1040 Bruxelles

Tel: (02) 230-4100

Tlx: 24501

Mr. J.H. Walsh

Department of Energy, Mines and Resources

580 Booth Street

Ottawa, K1A, OE4

Ontario

Tel:

T|x: 0534366

Mr. Paul Heinbecker

Canadian Del. to OECD

19 Rue de Franquelle

75016 Paris

Tel: 524.98 .04

Mr. J. Lemming

Head of Section

Ministry of Trade, Industry and Shipping

Slotscholmsgade 12

DK 1216 Copenhagen $\mathrm{K}$.

Tel: (01) 121197

TIx: 22373 
Germany

Greece

Ireland

Italy

Japan
Dr. H. Klein and Dr. Jacobs

Bundesministerium fuer Forschung and Technologie

Postfach 120370

D-53 Bonn 12

Tel: (Bonn) 593288

Tlx: 885674

Mr. J. Tzitzis

Greek Delegation to OECD

15 Villa Said

75116 Paris, France.

Tel: 500-0836

Mr. J.G. Duggan

National Science Council

St. Martin's House

Waterloo Road

Dublin 4

Tel: (3531) 767990

Tlx: 4651 ENCD-EL

Mr: Hugh Finlay and

Mr. Gerard McMahon

National Board for Science and Technology

Shelbourne House

Shelbourne.Road

Dublin 4

Tel: (01) 683311

T|x: 30327 NBST E1

Dr. Marzio Mangialajo

C/OPFE/CNR

Via Nizza, 128

Rome

Tel: 8440025 (Rome)

TIx: 612322 CNR PFE

Mr. Takada

Director

Conservation Programmes,

MITI

Kasumigaseki 1-3-1

Chiyoda-Ku, Tokyo

Tel:

TIx: J22916

Mr. T. Mukai

Japanese Delegation to OECD .

7 avenue Hoche

75008 Paris

Tel: 766-0222

TIx: 660493 
Luxembourg

Netherlands

Norway

Spain

Sweden
Mr. N. Molitor

Luxembourg Delegation to OECD

Ambassade du Luxembourg

33 Avenue Rapp

75007 Paris, France

Tel: 355-1337

Mr. J.A. Knobbout

Centre for the Study of Energy Problems (TNO)

Laan v. Wastenenk, 501

P.0. 342

Apeldoorn

Tel: (055) 773344

Tlx: 49095

Mr. R. Bolton

Chief Geothermal Engineer

Ministry of Works and Development

Box 12041

Wellington

Tel: None

TIx: 3844

Mr. Richard Benzie

New Zealand Delegation to OECD

7 ter, rue Leonard-de-Vinci

75116 Paris

Tel: $500-2411$

Mr. Torstein Pedersen

Ministry of Petroleum and Energy

P. O. Box 8148 Dep.

OSLO 1

Tel: None

TIx: 18680

Mr. Juan C. Llorrente and

Mr. Jose A. Gonzalez

Centro de Estudios de la Energia

Agustin de Foxa 29

Madrid 16

Tel: (Madrid) 227-3983

TIx: 27658

Mr. Per Strangert

Swedish Energy R\&D Commission

Sveavagen 9011

S-11157 Stockholm

Tel: (08) $763-3736$

TIx: 19350 
Mr. T. Sidenbladh

Industridepartementet

Fack

S-103 10 Stockholm 2

Tel: (08) 763-2164

TIx: 10590 (Foreign Office)

Mr. Lars Rey

National Swedish Board for Energy Source Dev.

Kistagoengen 4, Plan 4

Box 1103

S-163 12 Spoenga

Tel: (08) 752-0360

TIx: 12992

Switzerland

Dr. Christian Risch

Office of Science and Research

Wildhainweg, 9

Case Postale 2732

$\mathrm{CH}-3001$ Berne

Tel: (031) 619678

TIx: 33953

Mr. M. Roux, Eng.

Office Federal de l'Economic Energetique

Kappellenstrasse 14

$\mathrm{CH}-3001$ Berne

Tel: (031) 615624

TIx: 33065

Turkey

Mr. Y. Erguven

Conseiller Delegation

Delegation de la Turquie Pres de l'OCDE

184 Bld. Malesherbes

75017 Paris, France

Tel: 227-3272, 227-1075

United Kingdom

Dr. W.M. Currie

Energy Technology Support Unit

Atomic Energy Research Establishment

Harwell, Didcot

Oxfordshire, OX11 ORA

Tel: (0235) 24141, ext. 2578

T1x: 83135

Dr. G.F. Hewitt

Head of Thermodynamics Division

BIdg. 392, AERE

Harwell, Didcot

Oxfordshire, OX11 ORA

Tel: (0235) 24141, ext. 4408

TIX: 83135 


\section{United States}

Mr. Howard Ross, Head

Research \& Development Section

Architectural \& Engineering Systems Branch

Buildings Division

U.S. Department of Energy

Washington, D.C. 20545

Tel: (202) 252-9191

TIx: 578229249

Mr. R. Willitt

Office of International Affairs

U.S. Department of Energy

Washington, D.C. 20585

Tlx: 578229249

European Community

Dr. H. Ehringer

CEC, DG X11

200 rue de la Loi

B-1040 Bruxelles.

Belgium

Tel: (02) 735-0040

TIx: 26367 
THIS PAGE

\section{WAS INTENTIONALLY LEFT BLANK}




\section{APPENDIX C \\ Evaluation Methodology}

Worksheets for Evaluating DOE Participation in IEA Projects

Under the.Working Party on Energy Conśervation Research and Development

United States Department of Energy

Project Title:

Implementing

Agreement:

U.S. Program

Manager:

Project

Evaluation Team:

Project

Evaluation Date:

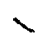

Contents

Introduction

Worksheets for Evaluating IEA Projects

- Worksheet A: Project Appraisal Method (p. 4)

- Worksheet B: Evaluation Comparison Chart (p. 9)

- Worksheet C: Project Management Evaluation Matrix (p. 10) 
The U.S. Department of Energy, (DOE) is responsible for coordinating U.S. involvement in the International Energy Agency (IEA) Working Party on Energy Conservation R\&D and for ensuring that U.S. interests are directly served by this involvement. These interests are defined by several objectives:

- Optimize domestic research, development, and demonstration (RD\&D) expenditures

- Promote the development of U.S. industries

- Contribute to the preservation of economic and political stability in the free world

- Strengthen the international position of the United States.

To achieve these objectives, the Working Party chairman has developed a method for evaluating DOE's participation in IEA projects to help individual program offices to determine the degree to which U.S. interests are served by such participation. Specifically, the method is designed to

- Provide DOE program offices with a common framework for measuring the merits of new and ongoing projects

- Help office directors conduct projects efficiently in order to maximize benefits for the U.S. and other participants

- Ensure consistency among U.S., DOE, and IEA Working Party yoals

- Clarify DOE.project objectives so that they can be communicated more readily to other IEA member nations

- Provide guidance to DOE and other federal agency personnel who are developing projects with representatives of other IEA nations

- Help the U.S. take a more active role in the IEA by systematically identifying projects that are most beneficial to the U.S.

Because of the differences in available resources, skill levels, and international involvement among program offices, the project evaluation method is designed to be flexible. Each program office can develop its own criteria to add to the ones already included in the evaluation method, or exclude some if they are not relevant to the program office. The method's scoring technique is unaffected by such changes.
The evaluation method can be applied by program offices in stages so that they can develop their evaluation capabilities incrementally. This method can also serve to complement other evaluation methods currently in use.

The project evaluation method also allows for input from knowledgeable outside experts, although it does not require such input. For example', it includes factors that help to assess the political and social criteria which the program office, depending on available resources, may wish to discuss with outside experts to ensure that , the evaluation is credible.

A project's final score can best be used to compare the merits of projects being conducted within the same program office. However, as program offices use the evaluation method more extensively, a basis for comparing scores among offices may be established.

In addition to using the project evaluation method, program offices cari take additional steps during project initiation or implementation to assure greater benefits and reduced cost to the United States. These actions include:

- Periodically contacting other working parties, government agencies (e.g., state energy offices), U.S. private industry, academic institutions, and end users to determine their need for and interest in international projects

- Publicizing projects in the Commerce Business Daily or trade publications in order to attract the interest and participation of qualified individuals and organizations

- Soliciting information from U.S. missions overseas on possibilities for cooperative action with IEA countries

- Consulting other working parties, agencies, and departments before accepting a new project, in order to avoid redundant or conflicting activities. 
The project evaluation method consists of three worksheets:

- Worksheet A, Project Appraisal Method, is a set of criteria for assessing the degree to which a project serves U.S. intẹrests.

- Worksheet B. Evaluation Comparison Chart, is a chart for comparing evaluations cónducted at different times in order to identify the areas in which ongoing projects have successfully achieved their goals.

- Worksheet C. Project Management Evaluation Matrix, is a set of questions to be used by project managers to assess overall project management and identify management issues that require attention.
Exhibit 1 outlines the situations in which the worksheets are used.

Exhibit 1

Project Evaluation

1

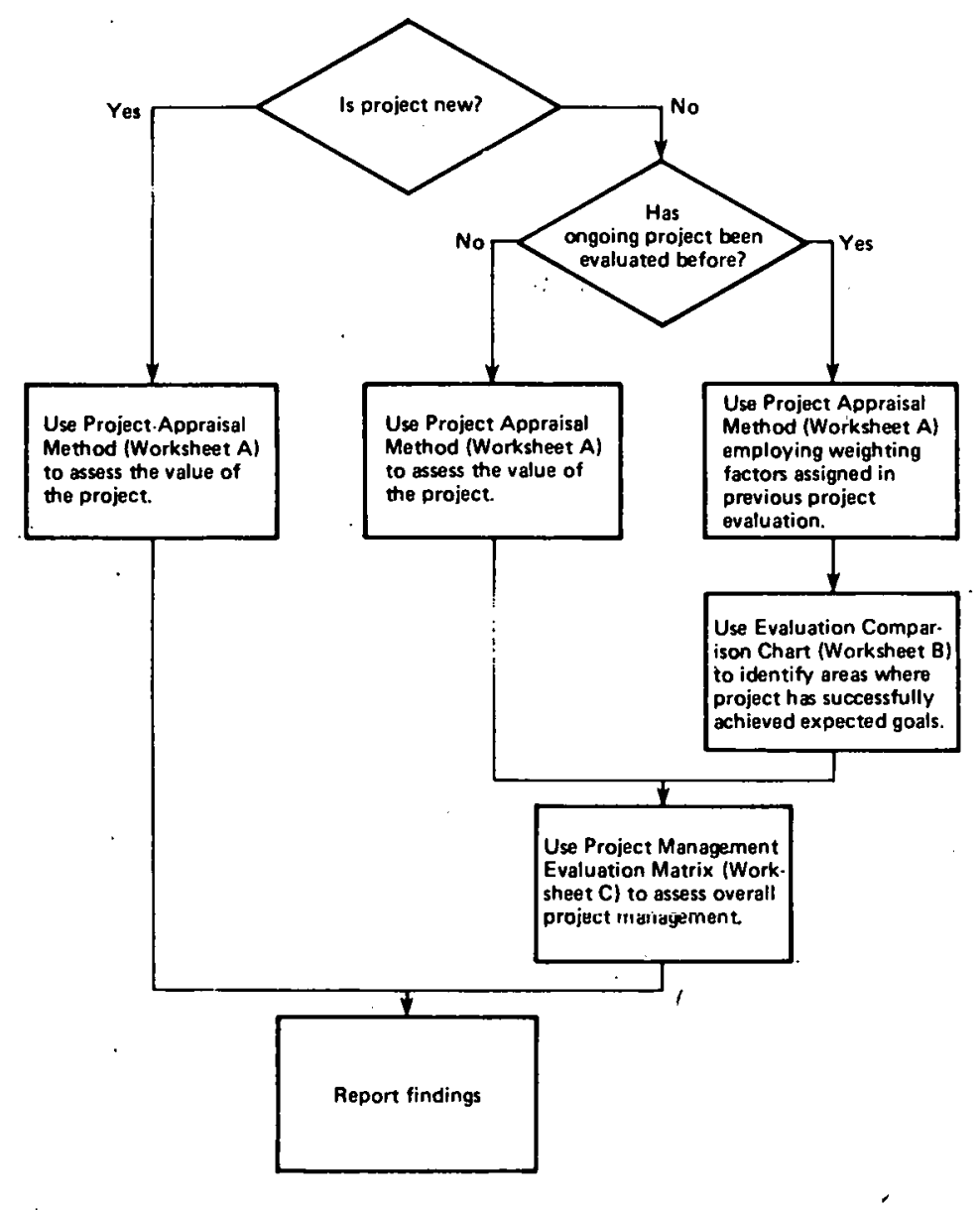




\section{Worksheet A \\ Project Appraisal Method}

To assess the potential benefits to the United States of participating in IEA projects, both direct and indirect economic, political, and social benefits must be considered. The project appraisal method consists of 9 criteria for determining such benefits, and a list of factors for quantitatively measuring each criterion. The project appraisal method is a three-step process:

\section{Step 1:}

- Read all criteria and assign a weighting to each criterion according to your juidgment of its respective importance. Each weighting will be between 0-100 and weightings for all 9 criteria should add up to 100 . Whenever there is more than one factor for any one criterion, distribute the weightings among each factor to arrive at an overall weighting for each criterion. Fill in the weightings in Column A. Use the space on page 8 to explain how you selected the weightings for each criterion and factor.
In the example below the first criterion has been given a weighting of 12 out of the total of 100 to be distributed among 9 criteria.

Step 2:

Estimate scores for each factor using the indicated ranges and fill in Column B. For example, if potential 1985 energy savings from the project are estimated to be $0.2 \mathrm{Mbbl} / \mathrm{day}$, then a score of 4 is assigned to the first criterion.

Step 3:

Multiply the weightings in Column A by their respective scores in Column B. Fill in Column $\mathrm{C}$ with the weighted scores just calculated, then add up Column $\mathrm{C}$ to find the total score for the project. The highest attainable score is 1,000 .

In the example below the weighted score is 48 .

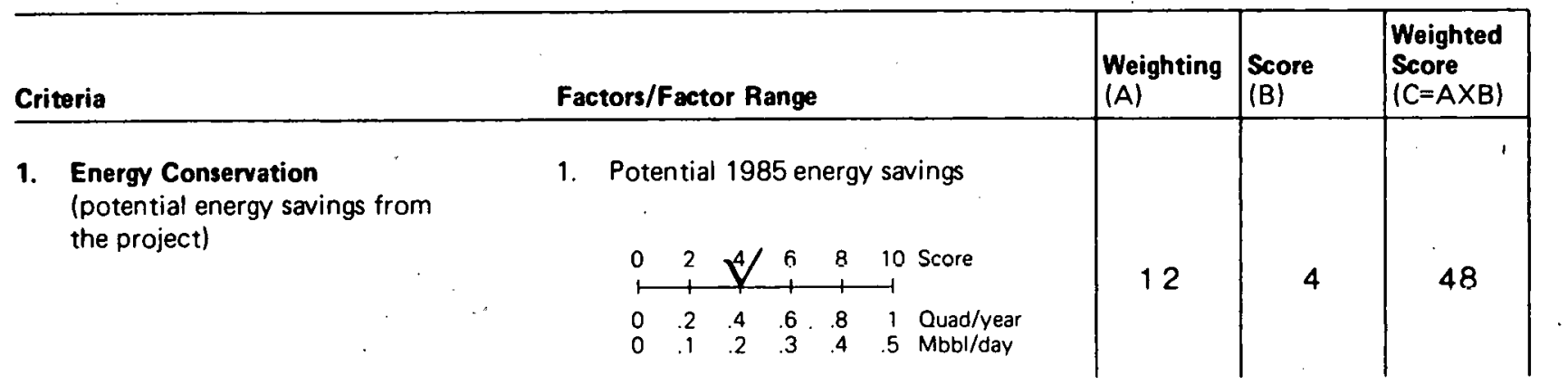




Criteria
$\begin{aligned} & \text { 1. Energy Conservation } \\ & \text { (potential U.S. energy savings from } \\ & \text { the project) }\end{aligned}$

2. Energy Substitution in the U.S. (depletable resources that can be replaced by more readily available resources as a result of the project)

3. U.S. Balance of Payment (BOP) (improvement in BOP that can result from savings in oil or gas or shifting to more readily available resources such as coal or solar as a result of the project)

4. Commercialization

(timing of the effect of the project on domestic and international energy problems)

5. Status of U.S. Technology (U.S. benefits from cooperating with countries that are at a more advanced technology level and that present no major barriers to information transfer, such as language or culture)
1. Potential 1985 energy savings

\begin{tabular}{|c|c|c|c|c|c|c|}
\hline 0 & 2 & 4. & 6 & 8 & 10 & Score \\
\hline & .2 & 4 & 6 & 8 & & Quad/year \\
\hline 0 & .1 & .2 & 3 & .4 & .5 & $\mathrm{Mbbl} / \mathrm{day}$ \\
\hline
\end{tabular}

2. Potential 1985 energy substitution

$\begin{array}{lllllll}0 & 2 & 4 & 6 & 8 & 10 & \text { Score } \\ 1 & 1 & 1 & 1 & 1 & -1 & \\ 0 & .2 & 4 & .6 & 8 & 1 & \text { Quad/year } \\ 0 & .1 & .2 & .3 & 4 & .5 & \text { Mbbl/day }\end{array}$

3. Potential improvement in the 1985 U.S. BOP

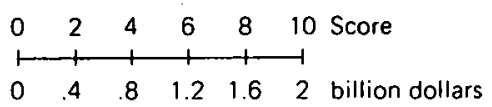

4. Estimated number of years to commercialization

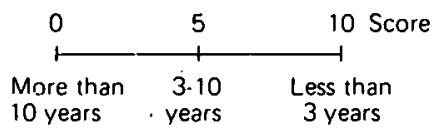

5a. Number of years U.S. technology is behind that of other participating countries

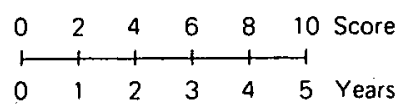

Weighting

(A)

Score
(B)

Weighted

Score

$(C=A \times B)$ 

transfer between cooperating countries and the U.S.

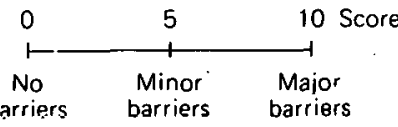

(increase in the number of energy supply options, particularly non-

(how much U.S. funding is required for the project?) gy transfer commercialization resulting from broad domestic participation in the project)

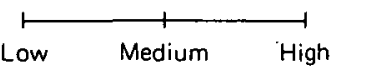

Effect on discouraging the use of

$\begin{array}{lll}\text { No } & \text { Minor } & \text { Major } \\ \text { effect } & \text { effect }\end{array}$

Effect on reducing oil imports 0

$\begin{array}{cll}\begin{array}{c}\text { No } \\ \text { effect }\end{array} & \begin{array}{l}\text { Minor } \\ \text { effect. }\end{array} & \begin{array}{l}\text { Major } \\ \text { effect }\end{array}\end{array}$

Effect on increasing the use of abundant or renewable mergy ources in other countries.

$\begin{array}{ccc}0 & \vdots & 10 \text { Score } \\ \text { No } & \begin{array}{l}\text { Mino } \\ \text { eft }\end{array} & \begin{array}{l}\text { Major } \\ \text { effect }\end{array}\end{array}$


Worksheet A

Project Appraisal Method (continued)

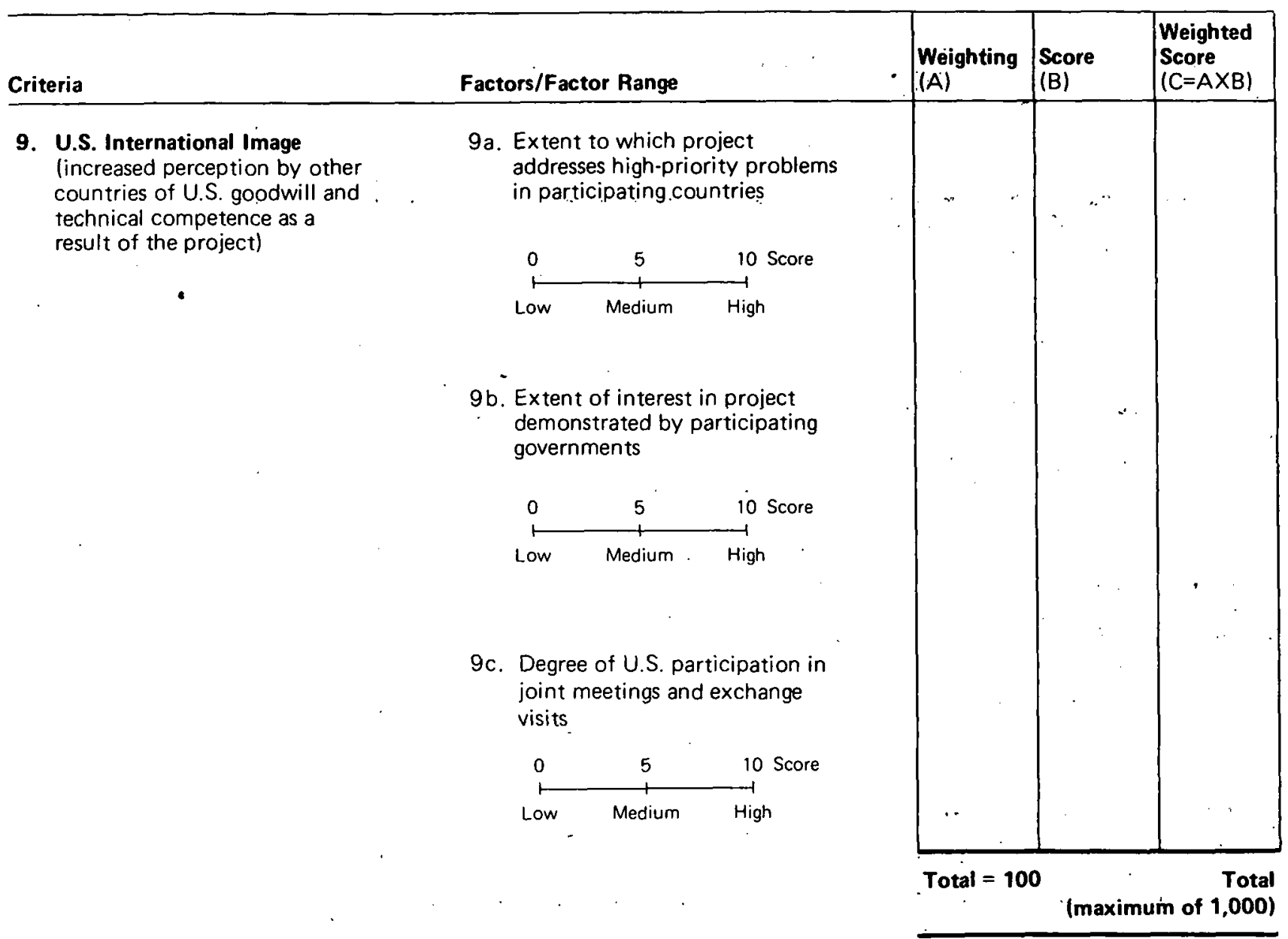


Worksheet A

Explanation of Relative Weightings

To make future evaluations of this project easier and more meaningful, it is important to record how you determined the relative importance of these criteria and factors. Accordingly, we ask you to use the space below to explain how you selected the relative weightings; i.e. why one criterion or factor was judged to be more important than another.

\begin{tabular}{l|c|c}
\hline Criteria & Weighting & Comment \\
\hline 1. Energy Conservation & & \\
\hline 2. Energy Substitution & & \\
\hline $\begin{array}{l}\text { U.S. Balance of } \\
\text { Payments (BOP) }\end{array}$ & & \\
\hline
\end{tabular}

4. Commercialization

5. Status of U.S. Technology

6. Share of Project Cost

7. Involvement of U.S. Industry

8. International Energy Options

9. U.S. International Image 
Worksheet B

Evaluation Comparison Chart

In order to identify areas where a project has successfully achieved its expected goals, the ongoing project scores are compared with the previous evaluation scores for all criteria. The information can be summarized in the chart below to help indicate areas where estimates of benefits have changed.

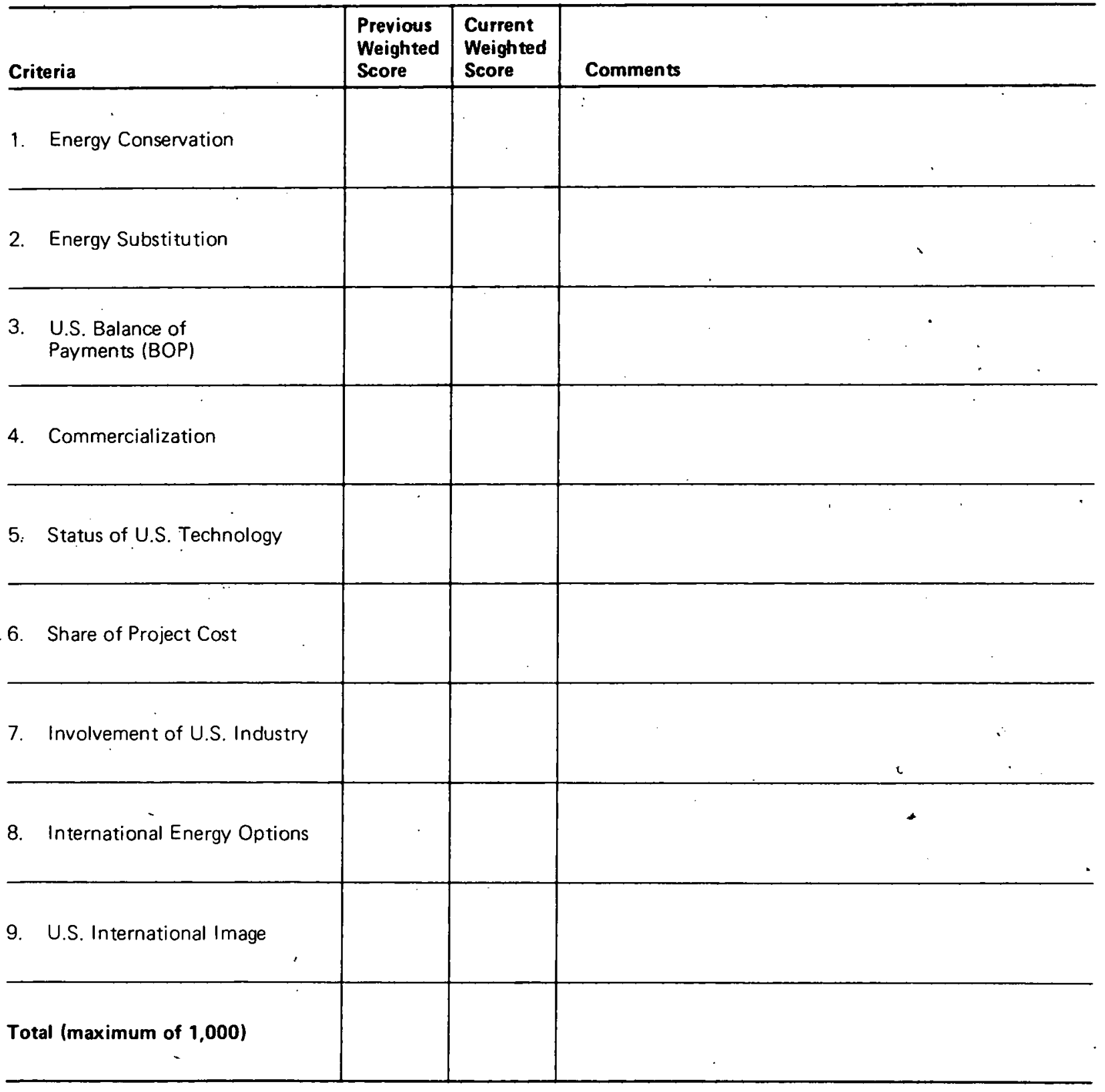


Worksheet C

Project Management Evaluation Matrix

To complete the evaluation of a project, three aspects of the project manàgement system must be analyzed: the funding arrangements, personnel management (e.g. availability and suitability of managers and technicians) and project control (e.g., use of milestones, schedules and reporting procedures). For international projects, these management issues must be analyzed for DOE, for other involved U.S. organizations, and for foreign agencies or firms participating in the project.

These issues can be summarized using a matrix as shown in the example; the matrix is used to identify project management issues that require attention and those areas that are adequately managed

\section{Example \\ Project " $A$ "}

Management Issue

\begin{tabular}{l|l|l|l|} 
Responsible Organization & Funding & Personnei & Control \\
\hline DOE & & & \\
\hline Other U.S. Organizations & 0 & & \\
\hline Foreign Agencies or Firms & 0 & 0 &
\end{tabular}

- major problem

O. minor problem

blank - insignificant problem

To assist in making assessments of these issues and completing the matrix below, a series of questions such as the ones presented in the remainder of this section must be answered.

\section{Management Evaluation Matrix}

\begin{tabular}{|c|c|c|c|}
\hline Responsible Organiżation & $\begin{array}{l}\text { Managem } \\
\text { | Funding }\end{array}$ & $\begin{array}{l}\text { Pent Issue } \\
\text { Personnel| }\end{array}$ & Control \\
\hline DOE & & & \\
\hline Other U.S.Organizations & & . & \\
\hline Foreign Agencies or Firms & & & \\
\hline
\end{tabular}

- major problem

O- minor problem

blank - insignificant problem 


\section{Project Managoment
Within tho DOE}

\section{Funding}

1.1 Has the project received adequate funding?

1.2 Have funds been allocated as planned?

1.3 Have funding allocations to International work been made without adversely affecting domestic projects?

\section{Personnel}

2.1 Have there been enough skilled technical personnel?

2.2 Has the project been managed "without jeopardizing domestic projects because of time demands on program personnel?

2.3 Were managers sufficiently familiar with the project?

\section{Control}

3. $1^{\circ}$ Have project milestones been defined and scheduled?

3.2 Have milestones been met on time?

3.3 Have project results been properly transmitted to other interested parties in the DOE?

Project Management Outside the DOE but Within the U.S.

\section{Funding}

1.1 Have subcontractors remained within the budget?

1.2 Have subcontractors had adequate funding?

1.3 Have subcontractors been paid on time in order that their work not be hampered?

\section{Personnel}

2.1 Has the technical competenice of U.S. subcontractors been adequate?

2.2 Has research been of ad. equate quality?

2.3 Have U.S. subcontractors indicated interest in the project by allocating their own funds to the same or similar projects?

\begin{tabular}{|l|l|l|l|}
\hline Yes & No & $\begin{array}{l}\text { Un- } \\
\text { cortain }\end{array}$ & \\
\hline & & & \\
& & &
\end{tabular}

\section{Control}

3.1 Have subcontractor milestones been defined and schedul ed?

3.2 Have subcontractor milestones been met on time?

3.3 Has project reporting been adequate?

3.4 Have project results been properly disseminated to interested parties in industry and academic institutions?

\section{Projoct Managament} Outside the U.S.

\section{Funding}

1.1 Have other " participating countries met their financial obligations on time?

1.2 Have cost-sharing arrangements been satisfactory?

2. Personnel

2.1 Have scientists been sufficiently competent and has re search been of adequate quality?

2.2 Are the participating countries in the project the.appropriate ones from the point of view of potential contributions to project objectives?

\section{Control}

3.1 Have milestones agreed upon initially been achieved as planned?

3.2 Has communication been adequate between U.S. scientists and researchers and those of other participating countries?

3.3 Has the project reporting been adequate? 